University of Nebraska - Lincoln

DigitalCommons@University of Nebraska - Lincoln

Papers in the Earth and Atmospheric Sciences

Earth and Atmospheric Sciences, Department

2008

\title{
Seismic facies and stratigraphy of the Cenozoic succession in McMurdo Sound, Antarctica: Implications for tectonic, climatic and glacial history
}

\author{
Christopher R. Fielding \\ University of Nebraska-Lincoln, cfielding2@unl.edu \\ Joanne Whittaker \\ Victoria University of Wellington, New Zealand, jo.whittaker@sydney.edu.au \\ Stuart A. Henrys \\ GNS Science, Avalon, Lower Hutt, New Zealand \\ Terry J. Wilson \\ Ohio State University, wilson.43@osu.edu \\ Timothy R. Naish \\ GNS Science, Avalon, Lower Hutt, New Zealand
}

Follow this and additional works at: https://digitalcommons.unl.edu/geosciencefacpub

Part of the Earth Sciences Commons

\footnotetext{
Fielding, Christopher R.; Whittaker, Joanne; Henrys, Stuart A.; Wilson, Terry J.; and Naish, Timothy R., "Seismic facies and stratigraphy of the Cenozoic succession in McMurdo Sound, Antarctica: Implications for tectonic, climatic and glacial history" (2008). Papers in the Earth and Atmospheric Sciences. 262. https://digitalcommons.unl.edu/geosciencefacpub/262
}

This Article is brought to you for free and open access by the Earth and Atmospheric Sciences, Department of at DigitalCommons@University of Nebraska - Lincoln. It has been accepted for inclusion in Papers in the Earth and Atmospheric Sciences by an authorized administrator of DigitalCommons@University of Nebraska - Lincoln. 


\title{
Seismic facies and stratigraphy of the Cenozoic succession in McMurdo Sound, Antarctica: Implications for tectonic, climatic and glacial history
}

\author{
Christopher R. Fielding, ${ }^{1}$ Joanne Whittaker, ${ }^{2}$ Stuart A. Henrys, ${ }^{3}$ \\ Terry J. Wilson, ${ }^{4}$ and Timothy R. Naish ${ }^{3}$
}

\begin{abstract}
1. Department of Geosciences, 214 Bessey Hall, University of Nebraska-Lincoln, NE 68588-0340, USA
2. School of Earth Sciences, Victoria University of Wellington, PO Box 600, Wellington, New Zealand

3. GNS Science, I Fairway Drive, Avalon, Lower Hutt, PO Box 30-068, New Zealand

4. School of Earth Sciences, 125 S. Oval Mall, Ohio State University, Columbus, OH 43210-1522, USA
\end{abstract}

Corresponding author - C. R. Fielding, email cfielding2@unl.edu

\begin{abstract}
Integration of data from fully cored stratigraphic holes with an extensive grid of seismic reflection lines in McMurdo Sound, Antarctica, has allowed the formulation of a new model for the evolution of the Cenozoic Victoria Land Basin of the West Antarctic Rift. The Early Rift phase (Eocene to Early Oligocene) is recorded by wedges of strata confined by early extensional faults, and which contain seismic facies consistent with drainage via coarse-grained fans and deltas into discrete, actively subsiding grabens and half-grabens. The Main Rift phase (Early Oligocene to Early Miocene) is represented by a lens of strata that thickens symmetrically from the basin margins into a central depocenter, and in which stratal events pass continuously over the top of the Early Rift extensional topography. Internal seismic facies and lithofacies indicate a more organized, cyclical shallow marine succession, influenced increasingly upward by cycles of glacial advance and retreat into the basin. The Passive Thermal Subsidence phase (Early Middle Miocene) is recorded by an evenly distributed sheet of strata that thickens somewhat into the depocenter but is continuous across and over the earlier rift strata to the margins of the basin. Internally, it contains similar facies to the underlying Main Rift, but preserves more evidence for clinoform sets and large channels, and in core comprises many short, condensed and strongly top-truncated stratal cycles with continued, periodic glacial influence. These patterns are interpreted to record accumulation under similar environmental conditions but in a regime of slower subsidence. The Renewed Rifting phase (Middle Miocene to Recent, largely unsampled by coring thus far) is represented by intervals that thicken significantly into the basin depocenter and that are complicated by evidence of magmatic activity (McMurdo Volcanic Group). This succession is further divided into lower and upper intervals, separated by a major unconformity that displays increasing angular discordance towards the western basin margin and Transantarctic Mountain Front. The youngest part of the stratigraphy was accumulated under the influence of flexural loading imposed by the construction of large volcanic edifices, and was formed in an environment in which little sediment was supplied from the western basin margin, suggesting a change in environmental (glacial) conditions at possibly c. 2 Ma. The Cenozoic stratigraphy of the southern Victoria Land Basin preserves archives of both climate change and the complex rift history of the basin, and coincidences between key stratal surfaces in seismic data and evidence for environmental change in drillcores suggest that tectonic and climatic drivers may be causally linked.
\end{abstract}

Keywords: seismic stratigraphy, seismic facies, Cenozoic, Antarctica, glacial, climate change 


\section{Introduction}

The Cenozoic evolution of the Antarctic paleo-environment is a topic of considerable current interest. A better understanding of long-term environmental change through the Cenozoic Icehouse climate regime can inform society about magnitudes, frequencies and cyclicity of warming and cooling that may help us adapt to future change, at a time of current instability in global climate. Because the polar regions are likely to preserve a relatively unmodified record of the most extreme climate changes, considerable effort has been expended in these areas, and in particular on Antarctica. Since there is limited exposure of sedimentary rock successions on the Antarctic continent, efforts have been focused on the continental margins in order to learn about long-term environmental history (millions of year timeframes). Much recent research has been carried out in the Ross Sea region of south-west Antarctica (Figure 1), for a variety of reasons including proximity to the major Antarctic research bases of the USA (McMurdo), New Zealand (Scott) and Italy (Mario Zucchelli). Among this research effort, several holes have been drilled by the Deep Sea Drilling Project (DSDP: Hayes and Frakes, 1975), and by scientific drilling consortia (Dry Valleys Drilling Project - DVDP: McGinnis, 1981; MSSTS-1: Barrett, 1986; CIROS-1 and -2: Barrett, 1989; Barrett and Hambrey, 1992; Cape Roberts Project - CRP: Cape Roberts Science Team, 1998, 1999, 2000). A number of seismic reflection surveys have also been carried out in the region, partly to provide the broader context to this drilling and to elucidate the structure and stratigraphic architecture of the West Antarctic Rift system, a failed Cenozoic rift that now forms the Ross Embayment (Cooper et al., 1987; Davey and Brancolini, 1995; Stagpoole, 2004).

In recent years, effort has increasingly focused on the westernmost part of the West Antarctic Rift System, a north-south-elongate sub-basin named the Victoria Land Basin (Figure 1). Data from fully cored drillholes, together with seismic reflection records, have shown that the Victoria Land Basin preserves a relatively complete archive of Cenozoic environmental change, from the Eocene onward. Our understanding of this crucial interval of time, which spans the onset of the current Icehouse regime (e.g., Zachos et al., 2001), has increased massively through these efforts, and additional drilling that is in progress (ANDRILL McMurdo Ice Shelf: MIS and Southern McMurdo Sound: SMS projects). At this time, however, no study has fully integrated the drilling dataset with information from the extensive array of seismic reflection records from the region (Figure 1).
In this paper, we present a stratigraphic framework for the southern Victoria Land Basin that is a modification and extension of that presented by Fielding et al. (2006). It draws on seismic reflection records from the McMurdo Sound region and integrates all available drilling data. The internal seismic reflection character of each stratigraphic interval is then described from oldest to youngest, and the insights that these data provide to understanding of Cenozoic basin history and environmental change are summarized.

\section{Stratigraphic framework}

A number of seismic reflection surveys have been carried out in the McMurdo Sound region, aimed at resolving the tectonic and stratigraphic history of this portion of the West Antarctic Rift, and in some cases providing two-dimensional subsurface imagery to support stratigraphic drilling projects (Figure 1). The first comprehensive, multi-channel seismic reflection survey and seismic stratigraphic framework for the region, was conducted and presented by Cooper et al. (1987), who divided the Victoria Land Basin succession into 7 seismic units (V1-V7, from youngest to oldest) divided by key reflectors that could be traced over the entire region (Table 1). Brancolini et al. (1995a, 1995b) presented a more detailed seismic stratigraphic analysis based on single- and multi-channel seismic reflection data, in which they defined eight seismic sequences (coded RSS1-8, from oldest to youngest), each separated by a key reflector interpreted as a seismic sequence boundary, or unconformity (coded RSU 1-6, from youngest to oldest: Table 1). Barrett et al. (1995) and Bartek et al. (1996), using single channel data, proposed a considerably more detailed seismic stratigraphic subdivision of the Cenozoic succession in western McMurdo Sound, in which they recognized twenty seismic sequences. They attempted correlations from these data into the stratigraphic drillholes MSSTS-1 and CIROS-1, and provided prognoses for the planned Cape Roberts Drilling Project further north along the western basin margin (Figure 1). The Cape Roberts holes were drilled in 1997-1999.

Henrys et al. (2000, 2001) acquired Vertical Seismic Profiles from the Cape Roberts Project drillholes, and on this basis provided detailed correlations to the lithostratigraphy, used by Fielding et al. (1998, 2000, 2001) to establish a tectono-stratigraphic model for the CRP succession. Hamilton et al. (2001) applied the seismic stratigraphic schemes of Cooper et al. (1987) and Bartek et al. (1996) to seismic data in the region of the Cape Roberts Project drillsites, and also proposed cor- 
Figure 1. Location maps. A) Regional context: Ross Sea rift basins and Transantarctic Mountains are components of the West Antarctic Rift System (see inset). B) Detailed map of southern McMurdo Sound showing the seismic reflection (bold black lines) and drillhole data (filled drillhole symbols) used herein, and the different physiographic zones recognized. The location of the McMurdo Ice Shelf (AND-1B) borehole is shown by an open drillhole symbol. The cross-hatch pattern indicates the extent of volcanic rocks identified on seismic reflection and swath bathymetry data.

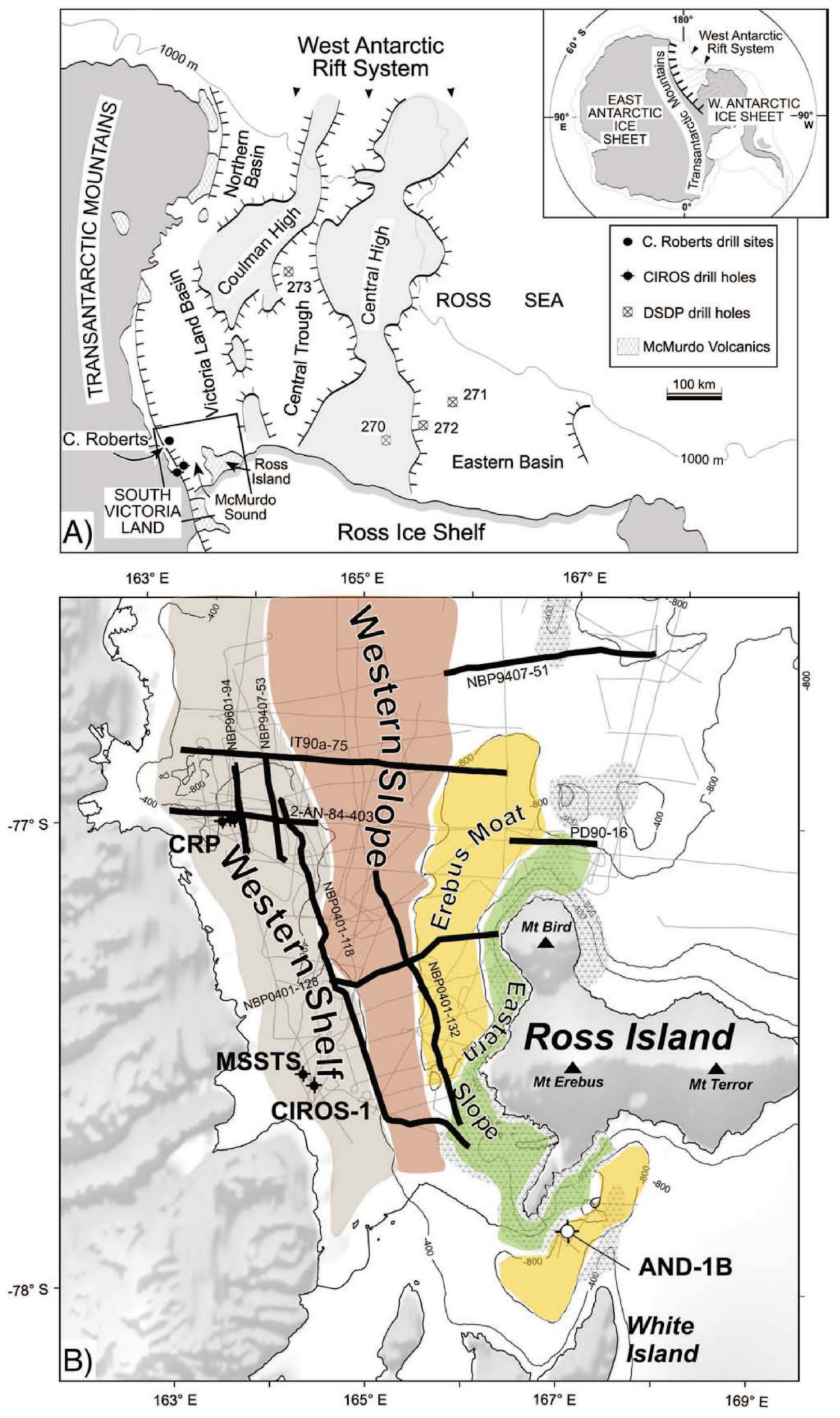


relations with the lithostratigraphy in those fully cored holes. However, their correlation from the seismic data to the cores differs substantially from that of Henrys et al. $(2000,2001)$, and is considered to be in error (Fielding et al., 2006).

Recently, new seismic reflection data have been acquired as part of the preparations for the ANDRILL MIS project south of Ross Island (Naish et al., 2006), and a seismic stratigraphic analysis was reported by Horgan et al. (2005). An extensive, multi-channel seismic reflection survey was also conducted in 2004 (RVIB Nathaniel B. Palmer cruise 0401; Wilson et al., 2004) to provide data in areas previously uninvestigated by seismic reflection traverses (Figure 1). Some results from this cruise were incorporated into the work of Whittaker (2005) in southern McMurdo Sound.

Fielding et al. (2006) presented a new seismic stratigraphic framework for the McMurdo Sound region, incorporating all available seismic reflection data, and propagating correlations outward from the Cape Roberts area where core to seismic correlations are well-established. The scheme recognizes numerous laterally traceable events, many of which correlate to key surfaces of Cooper et al. (1987), Brancolini et al. (1995a, 1995b), and Bartek et al. (1996). However, it adopts a basic framework and philosophy similar to that of Cooper et al. (1987), and divides the basin fill into five tectonostratigraphic phases (Table 1). The model for basin evolution is presented elsewhere by Wilson et al. (submitted for publication) and summarized in Fielding et al. (2006). This scheme is adopted and augmented herein with newly-recognized and -propagated events for particularly the uppermost part of the stratigraphy (Table 1). Age estimates for some of these younger events are provided by Naish et al. (in press).

\section{Methods}

In this work, seismic reflection data from all surveys carried out in McMurdo Sound, up to and including NBP0401 and MIS surveys, were imported into Schlumberger Geoquest (C) interpretation software. Navigational data were used to correct some older lines to a linear distance scale. Seismic lines were then interpreted on a work-station, using cross-line functions to provide realistic four way and other stratigraphic ties. Paper prints were also interpreted independently to serve as a quality control mechanism. Seismic data quality in the area is compromised by the presence of a strong sea-floor multiple due to ice cover, and associated "ringing" effects. Interpretations in the critical Cape Roberts area were assisted by the re-processing of L2-AN-84-403/404 (Cooper et al., 1987) at GNS to mitigate multiple effects. Regional interpretation of this line is presented by Wilson et al. (submitted for publication), and the area of the CRP drillholes is described by Fielding et al. (2006).

To establish the geometry of seismic facies we have mostly used data that have only been corrected for spherical spreading of the source with no other gains applied. However, L2-AN-84-403/404 has been processed through to migration and an AGC applied for the purpose of imaging the deeper structure of the basin. The L2-AN-84 survey (Dadisman et al., 1987) was acquired with a $1311 \mathrm{in}^{3}$ airgun source and data are lower frequency $(<20 \mathrm{~Hz})$ than all the other data used (bandwidth $10-80 \mathrm{~Hz}$ ) which were acquired with GI-Guns, single Bolt airguns, or small $(3.2 \mathrm{~kg})$ explosive charges (on-ice) and have similar signal penetration. Amplitude data have not been normalized across all the surveys, and no maps of amplitude or other properties are compiled herein to assess facies variability. Nonetheless, data presented still preserve relative reflection geometry information.

\section{Seismic facies}

Seismic facies have been previously characterized for the Cenozoic succession of the Ross Sea region in general by Anderson and Bartek (1992), and Brancolini et al. (1995a), among others. Some more site-specific seismic facies analysis and modeling was carried out by Bartek et al. (1997) in the central and eastern parts of the West Antarctic Rift, and details of seismic facies in the area of the CIROS- 1 and MSSTS- 1 drillholes were provided by Bartek et al. (1996) and Bucker et al. (1998). More recently, seismic facies in the youngest part of the stratigraphic section, in southern McMurdo Sound, were evaluated by Horgan et al. (2005) and Whittaker (2005). The present work draws on these previous studies, and extends both the array of seismic facies recognized and the stratigraphic range to include the entire Cenozoic. We present analysis of seismic facies in their stratigraphic context in order to assess their contribution to understanding changing paleo-environment through time. 
Table 1. Seismic stratigraphic framework for this study, showing interpretation in terms of rift history and correlation to other seismic stratigraphic schemes for the region (modified after Fielding et al., 2006)

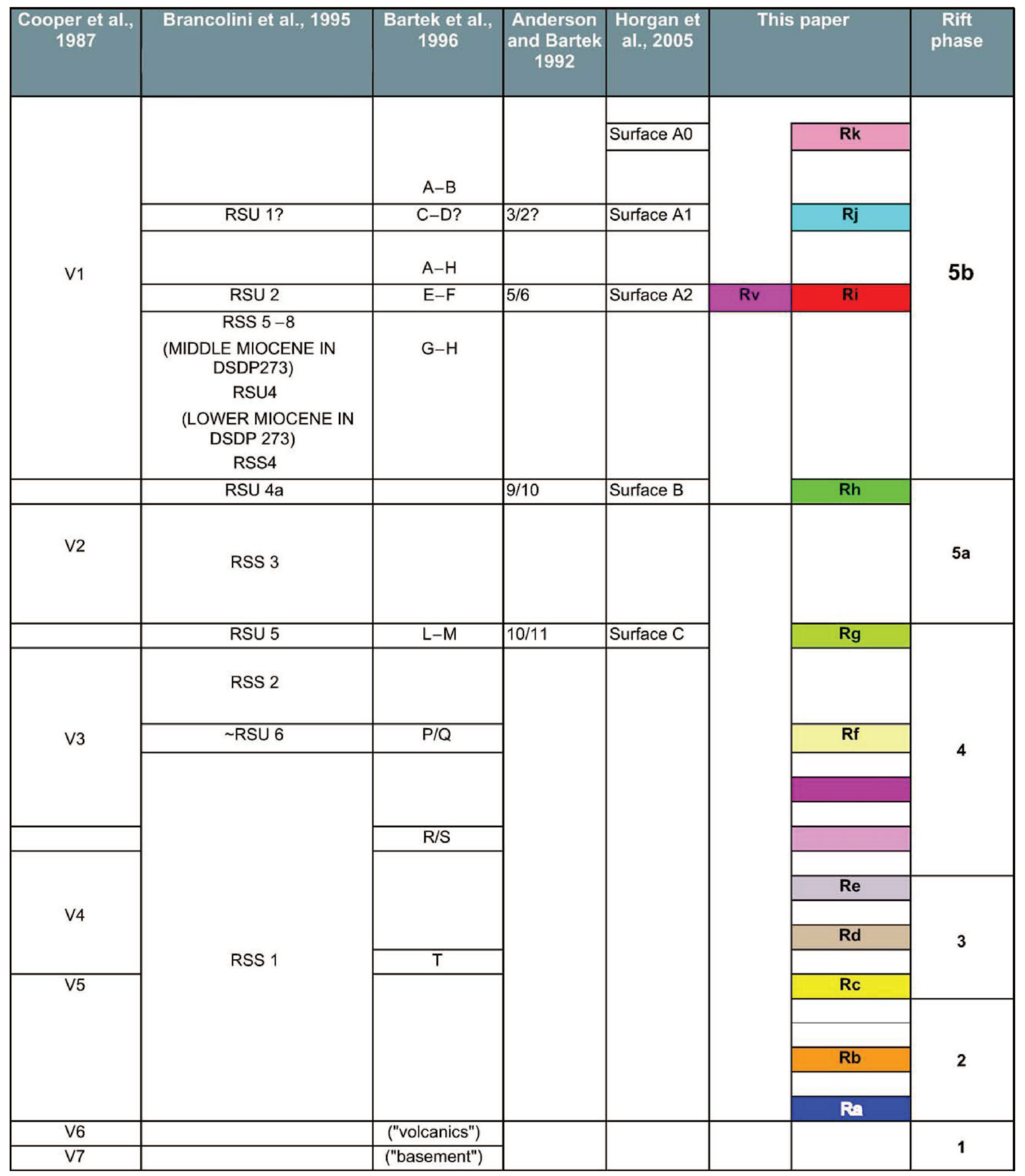

1 - Exhumation of the Transantarctic Mountains; 2 - Early Rift; 3 - Main Rift; 4 - Passive Thermal Subsidence; 5a - Renewed Rifting, lower interval; $5 b$ - Renewed Rifting, upper interval. Flexural loading of the lithosphere in the region around Ross Island commenced at about the time of the turquoise reflector. Color codes for key seismic reflectors are those used in illustrations herein. 


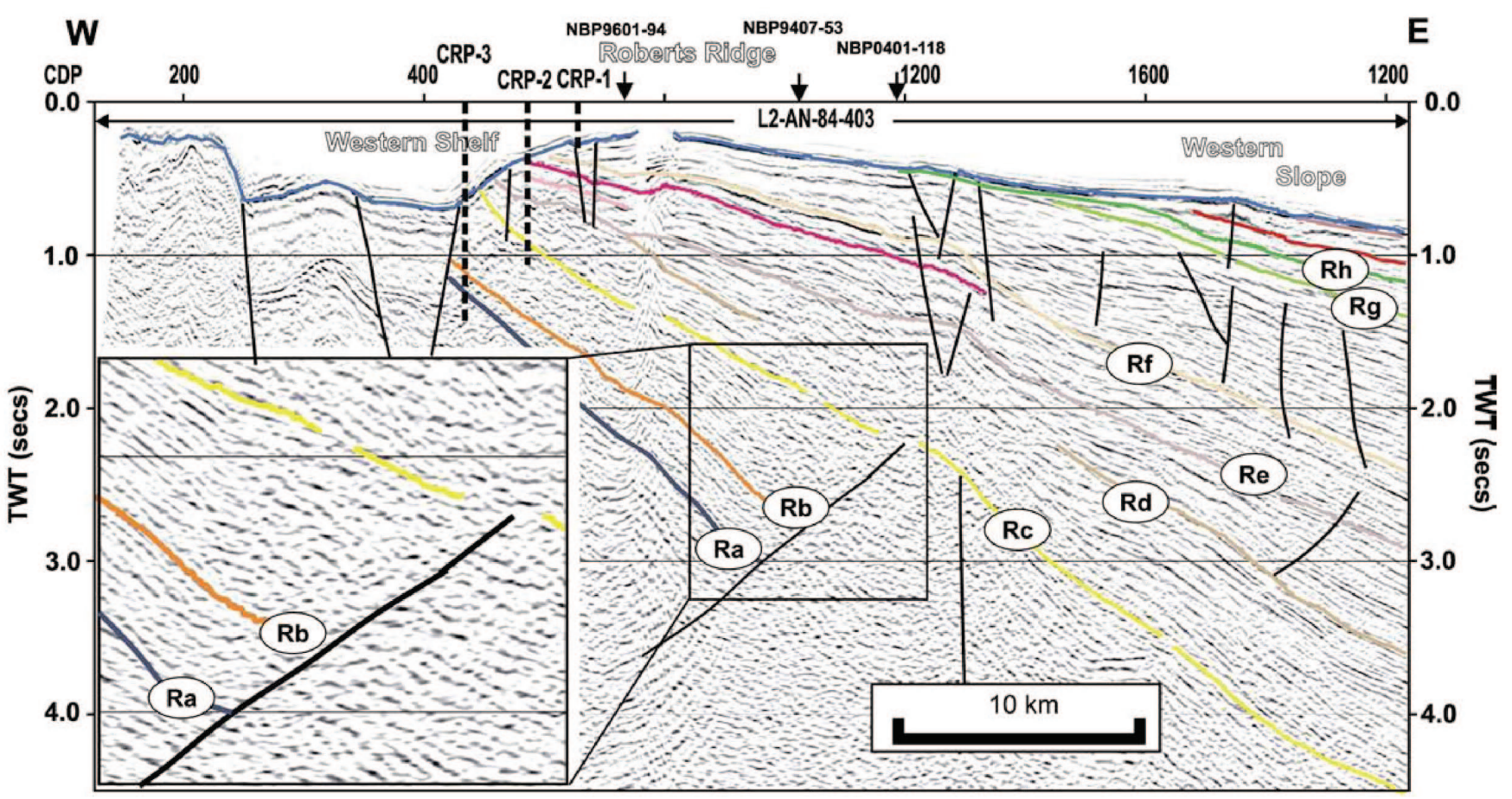

Figure 2. Westernmost part of the re-processed seismic reflection dip line L2-AN-84-403 (Figure 1) showing rift architecture close to the western edge of the Victoria Land Basin (Western Shelf). Inset shows close-up view of the principal seismic facies of the Early Rift (navy blue - Ra to yellow - Rb reflectors) and Main Rift (yellow - Rb to purple-grey - Rc) successions. In the Early Rift section, mainly concordant, moderately continuous, high amplitude events with some low-angle clinoforms pass downdip into a chaotic seismic fabric adjacent to the half-graben-bounding fault. In the Main Rift section, mainly concordant events of similar character to the underlying section dominate, and are continuous across the top of earlier extensional topography. See Table 1 for key to reflectors.

\subsection{Early Rift interval (navy blue to yellow reflectors of Fielding et al., 2006)}

The Early Rift section (Eocene to Lower Oligocene: 34-29 Ma) is buried deeply in much of the area covered by seismic reflection data, and thus lies below the first sea-floor multiple. It approaches the sea-floor towards the western margin of McMurdo Sound, however, and was penetrated by CRP-2A and -3 . There $(823 \mathrm{mbsf}$ to top of CRP-3 and 624-443 mbsf in CRP-2A) it comprises a basal conglomerate and breccia-dominated interval of interpreted subaerial to subaqueous fan origin, overlain by a thick section of sandstone with subordinate gravelly sandstone and conglomerate accumulated in probable marine environments under a regime of very rapid subsidence (Cape Roberts Science Team, 1999, 2000]). A similar section was also penetrated in the lower half of CIROS-1 (below a major unconformity at $366 \mathrm{mbsf}$ ), although this lies entirely below the first sea-floor multiple in seismic data crossing the well site. The oldest Cenozoic strata in CRP holes were estimated as $34 \mathrm{Ma}$ in age, and in CIROS-1 35-37 Ma (Hannah et al., 1997; Wilson et al., 1998), while ex situ glacial erratics from the margins of the basin contain fossils suggesting a mid- dle to late Eocene age (44-35 Ma: Bohaty and Harwood, 2000).

Seismic data that show the Early Rift section clearly are mostly in the region around the CRP drillholes, where the synrift section approaches the sea-floor. These data are augmented by the reprocessed L2AN-84-403/404, from which the sea-floor multiples have been largely removed, allowing clear visualization of the synrift section as far downdip as the first half-graben bounding fault (Figure 2). The Early Rift section overlies a reflector that is interpreted to represent the basement unconformity (navy blue reflector) and is confined laterally by a series of apparently steeply-dipping, normal faults that cut basement. In the area of Roberts Ridge, the Early Rift interval forms an eastward-thickening wedge that is abruptly truncated against the first major basement-offsetting fault. Within the Early Rift section, the principal seismic facies are 1. irregular to chaotic, discontinuous, moderate to high amplitude reflections in the updip area, passing downdip into 2. mainly concordant, parallel to somewhat irregular, semi-continuous reflections of moderate to high amplitude and moderate frequency, with local development of clinoform sets, in turn passing into 3 . chaotic to reflec- 
tion-free facies in the immediate hangingwall region of the half-graben-bounding fault (Figure 2).

Although these patterns cannot be confirmed regionally, relationships in seismic reflection line L2AN-84-403/404 suggest that these seismic facies correspond to the subaerial to subaqueous fans mentioned above, passing downdip into generally coarse-grained shallow marine deposits. At times, sufficient standing water formed as to allow progradation of deltas into the hangingwall depocenter. Adjacent to the fault, these facies likely passed into disorganized, footwall-derived colluvial deposits (cf. Blikra and Nemec, 1998) accumulated in base-of-slope systems along the immediate hangingwall of the half-graben-bounding fault (cf. Ravnås and Steel, 1998; Gawthorpe and Leeder, 2000). The CRP drillholes provided lithological sample of the updip seismic facies, which are overwhelmingly sandstone- and conglomerate/breccia-dominated fan deposits typical of the gently-tilted hangingwall block of half-grabens (cf. Ravnås and Steel, 1998; Gawthorpe and Leeder, 2000]).

\subsection{Main Rift interval (yellow to purple-grey reflectors of Fielding et al., 2006)}

The Main Rift section (Lower to Upper Oligocene: 29-23 Ma) is also buried deeply over much of the survey area, and again is best-imaged in the area of the Roberts Ridge. This interval was penetrated in CRP-2/2A, where it comprises the interval 443-130 mbsf. Lithologically, this interval is more diverse, with increasing proportions of diamictite, abundant sandstone, and lesser conglomerate, heterolithic sandstone-siltstone, and mudrocks (Cape Roberts Science Team, 1999). The Main Rift interval is readily divided into genetic cycles or "sequences", and its uppermost part comprises three unusually thick and complete sequences which were analyzed in detail by Naish et al. (2001) and Dunbar et al. (2008). The section was interpreted as the products of mainly shallow, open marine environments, periodically affected by the advance and retreat of grounded ice across the Roberts Ridge area.

Seismically, the fundamental characteristic of the Main Rift interval is that it forms a regionally extensive body in cross-section that thickens significantly towards a depocenter in the centre of the Victoria Land Basin. The thickness distribution of this interval is influenced somewhat by underlying extensional topography. The basal yellow reflector is the lowermost horizon that can be traced across the top of the first basement horst, and thus is interpreted to have formed when the locus of subsidence shifted eastward from early grabens and half-grabens to a more axial location within the Victoria Land Basin. The yellow event correlates to a major discontinuity at $443 \mathrm{mbsf}$ in CRP-2A, as does the neartop of the Main Rift section (purple-grey reflector) at 186 mbsf in CRP-2A. Internally, the principal seismic facies in the lower half of this interval under the Roberts Ridge comprises moderately continuous, moderate frequency, high-amplitude, generally parallel reflections, with some poorly-defined channel forms evident locally (Figure 2). Within the upper part of the section, however, corresponding to the thick sequences noted above (Sequences 9-11: Naish et al., 2001), clinoform geometries are evident from seismic data, showing an apparent eastward progradation direction. This upper part of the Main Rift succession is expressed as a prominent, eastward-thickening wedge in seismic lines that pass close to CRP drilling sites (Henrys et al., 2000; Fielding et al., 2000), suggesting a strong tectonic control on accommodation at this time. Downdip to the east, the seismic facies becomes one of more distinctly parallel cross-sectional geometry, with continuous, moderate frequency and high amplitude events dominant ("tramlines": Figure 2).

The patterns described above are interpreted to record Oligocene sediment dispersal from west (Dry Valleys and Transantarctic Mountains) to east (i.e., transversely) into the then growing Victoria Land Basin. Lithofacies and biofacies information indicates that sediments accumulated in shelfal water depths, at least in proximal areas such as the CRP drillsites (Barrett and Ricci, 2000). Accommodation was increasing to the east during this period, and so the proximal region sampled by CRP cores is characterized by successions of thin, incomplete, condensed and strongly top-truncated sequences (Fielding et al., 2000) that presumably would become thicker and more complete eastward. This period was also increasingly affected by cycles of glacial advance and retreat across proximal areas, and many sequence boundaries and regionally extensive reflectors may owe their origins to glacial scouring. However, little evidence of erosional relief, such as channeling, or depositional relief, such as morainal ridges, is evident from this interval. Clinoform sets evident from seismic data in the upper part of the Main Rift interval suggest progradation of coarse clastic wedges into marine waters, consistent with the coarsening-upward intervals recorded in CRP-2A core (Fielding et al., 2000; Naish et al., 2001). The top of the Main Rift interval, at the top of Sequence 9 in CRP2A, coincides with the Oligocene-Miocene boundary at 23.02 Ma according to new calibration of data from CRP-2/2A (Naish and Wilson, 2008; Barrett, 2007), and 


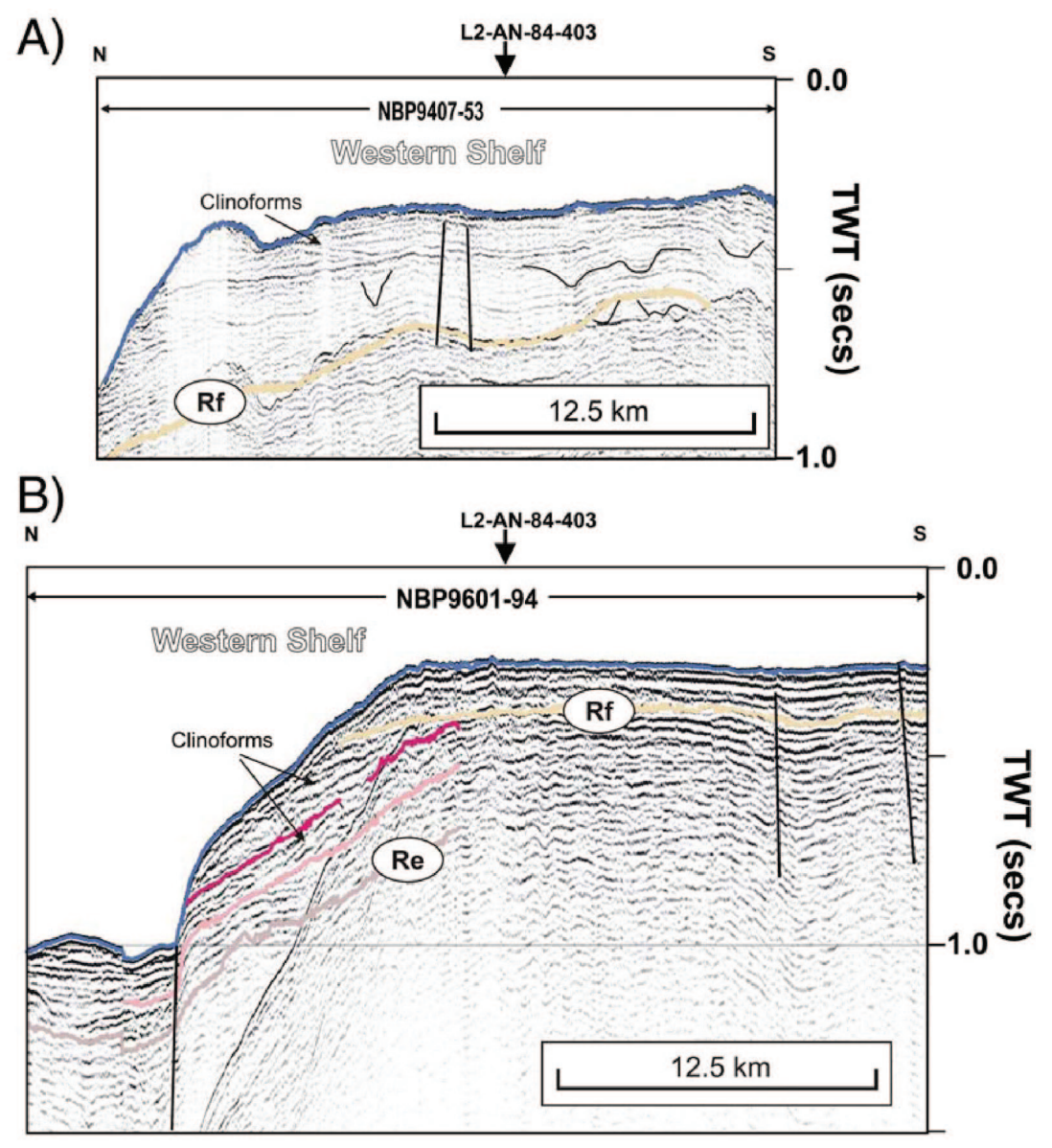

Figure 3. Seismic facies of the Thermal Subsidence phase in strike lines on the Western Shelf. A) Part of line NBP9407-53, showing channels (bold black lines) incised into the section both below and above the beige event (Rf), and clinoforms (labeled) in the uppermost part of the section. B) Part of line NBP9601-94, showing clinoform sets in the pink to crimson and crimson to beige (Rf) intervals (arrowed). See Table 1 for key to reflectors and Figure 1 for location of data.

is thus coincident with a major climatic deterioration (Mi-1 glaciation of Miller et al., 1991).

\subsection{Passive Thermal Subsidence interval (purple-grey to light green reflectors of Fielding et al., 2006)}

The Passive Thermal Subsidence section (Lower to Middle Miocene: 23- $13 \mathrm{Ma}$ ) is visible in seismic data over a much wider area than the underlying intervals, as it is more extensively imaged above the first sea-floor multiple. The lower part of the interval was sampled in the uppermost $130 \mathrm{mbsf}$ of CRP-2/2A, and in the entire pre-Pliocene section of CRP-1. However, Fielding et al. (2006) note that a significant overlying section also attributed to this interval remains as yet unsampled by drilling. In the sampled interval, the lithology is similarly diverse to the underlying Main Rift, with abundance of diamictites increasing upward. Furthermore, sequences are even more condensed, incomplete and severely top-truncated than below, suggesting a regime of lower accommodation (consistent with interpreted slower subsidence rates) and potentially more frequent and deeper scouring during glacial advances across proximal regions.

Seismically, the Passive Thermal Subsidence succession is characterized by a sheet-like cross-sectional geometry, thickening into the central Victoria Land Basin depocenter but with no abrupt lateral changes in thickness, and continuously covering earlier Synrift strata to the basin margins. The basal purple-grey reflector corresponds to a pronounced angular unconformity in some seismic lines, which Fielding et al. (2006) suggested could record a "rift-drift" or synrift-postrift unconformity. This horizon also appears to immediately precede the onset of the Mi-1 glaciation, as noted above. Within the interval, a further laterally persistent horizon has also been mapped (beige reflector), which marks the approximate top of the pre-Pliocene section in CRP drillholes, dated at c. $17 \mathrm{Ma}$. This reflector may record a regionally extensive unconformity (see, for example, 


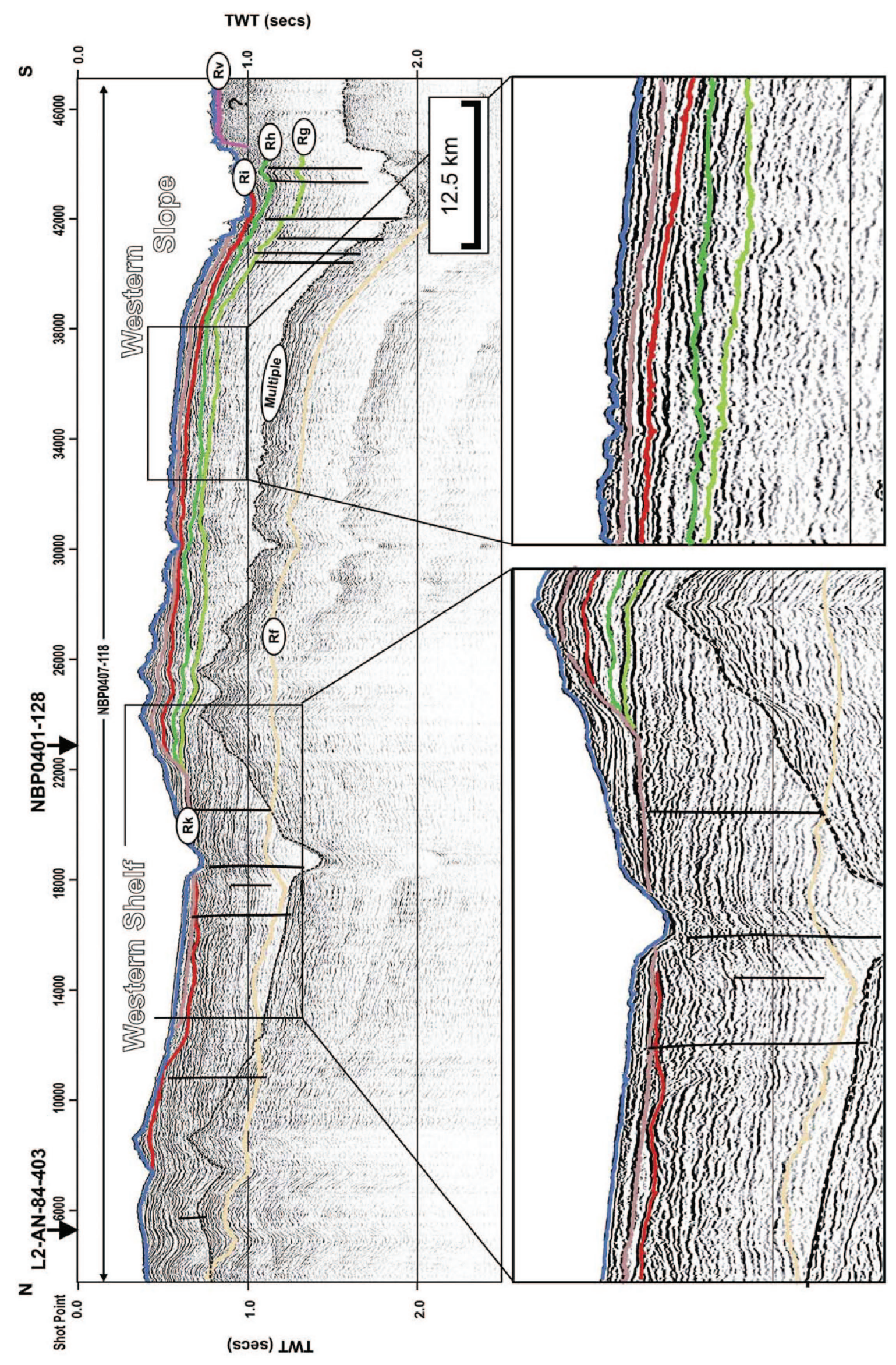

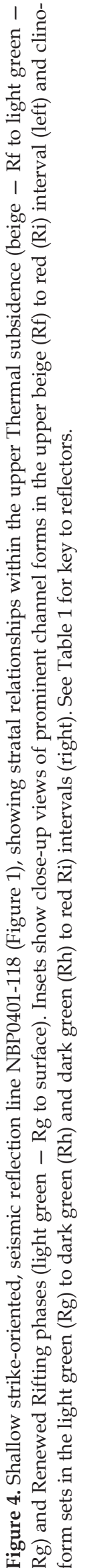




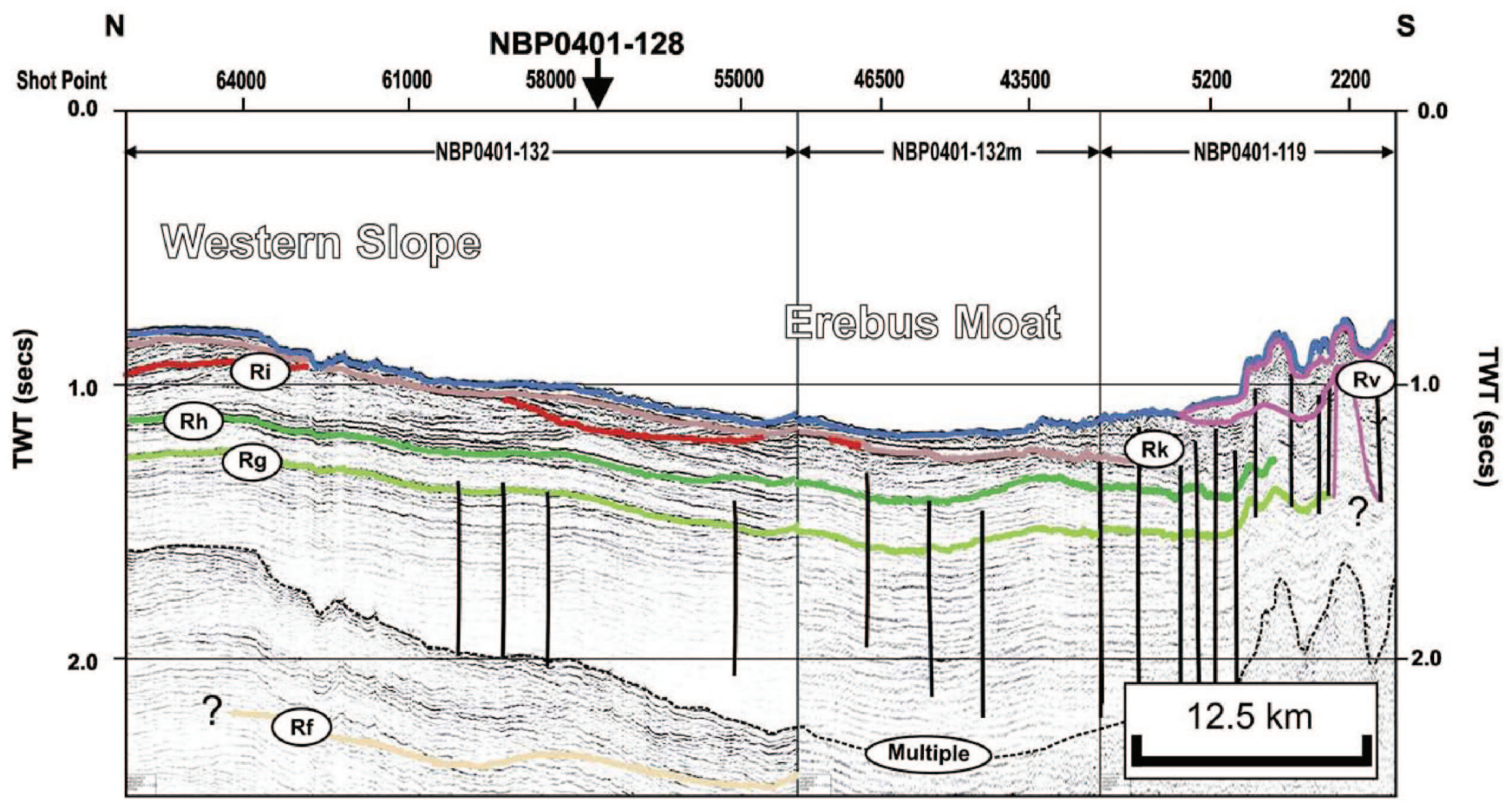

Figure 5. Deep, strike-oriented seismic reflection line NBP0401-132 (Figure 1), showing stratal relationships in the upper Thermal Subsidence (beige - Rf to light green - Rg) and Renewed Rifting (light green - Rg to surface) phases. Note the abundant clinoform sets in the dark green $(\mathrm{Rh})$ to red $(\mathrm{Ri})$ interval in the northern half of the line. See Table 1 for key to reflectors.

Figure 3B), as it has also been mapped into the area of CIROS-1 where it separates Lower Miocene strata (c. $23 \mathrm{Ma}$ ) below from Pliocene strata above, and into MSSTS-1 where it separates Lower Miocene below from strata of unknown age above (Harwood et al., 2006, and Harwood, unpublished data). The upper limit to the Passive Thermal Subsidence interval is taken at the light green reflector ( 13 Ma: Naish et al., in press), which records an upward transition to a younger section that again thickens into the central depocenter, and is associated with renewed faulting and magmatic activity. The light green reflector is also a major seismic sequence boundary, and could indicate a significant change in lithology associated with either or both tectonic reorganization or/and environmental change. Seismic facies within the Thermal Subsidence interval are similar to those of the underlying Main Rift, with two important differences: 1 . there is significantly more widespread evidence for channeling at various stratigraphic levels on the Western Shelf, mainly evident in north-south strike lines and 2. clinoform sets, indicating various apparent directions of progradation, are widespread in this interval (Figures $3 \& 4$ ). As with the underlying section, however, little evidence of positive depositional relief, such as might be formed by morainal ridges, was noted.

The described cross-sectional geometries and seismic facies are interpreted to record continued sediment dispersal eastward from the Dry Valleys region into the Victoria Land Basin through at least the Early Miocene. Sediment accumulation, at least in the lower part of the interval, was in shelfal marine environments, with increasing influence from glacial advance-retreat cycles through time. Advance of grounded glaciers during this period across the Western Shelf caused incision of some sizeable channel forms (10s of meters in depth, hundreds of meters to kilometers in width), but dip-oriented seismic sections indicate a generally sheet-like cross-sectional geometry for sequences in that direction. Given the interpreted slower subsidence rate during this interval, the increased incidence of scoured channel forms need not indicate a more austere climatic regime, but rather may reflect a greater likelihood of formation and preservation of channel forms. Widespread preservation of clinoform sets suggests continued progradation of coarse clastic wedges/lobes into the basin through this time.

\subsection{Renewed Rifting (Terror Rift) interval, lower part (light green to dark green reflectors of Fielding et al., 2006)}

The term "Terror Rift" has been applied to the stratigraphic section overlying the light green reflector. This interval thickens markedly across faults that cut the up- 


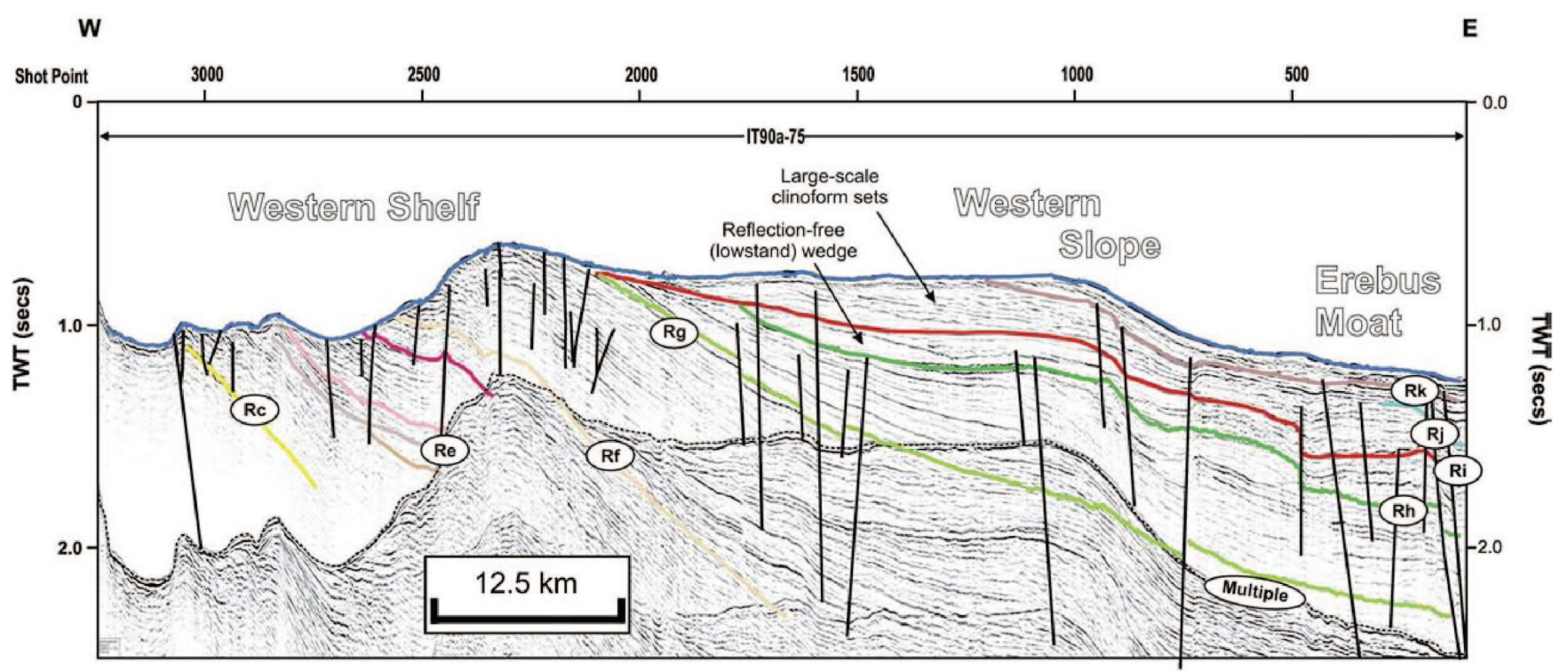

Figure 6. Seismic reflection dip line IT90a-75 (Figure 1), showing seismic stratigraphy and facies of the upper Thermal Subsidence (beige to light green events) and overlying Renewed Rifting (light green - Rg to sea floor) phases on the Western Shelf and Slope. See Table 1 for key to reflectors. Note the dominantly parallel, concordant to mildly divergent, continuous, moderate to high amplitude reflection character, with some channel forms and clinoforms, typical of the beige (Rf) to dark green (Rh) interval, and the major change in seismic character across the dark green (Rh) reflector. Immediately above Rh is a reflection-free (interpreted lowstand) wedge form (arrowed) located on the lower part of a paleo-depositional slope, that is onlapped and downlapped by subsequent reflectors up to the red (Ri) reflector. Above the red horizon is a further possible lowstand wedge, overlain by a stack of large-scale clinoform sets (arrowed) associated with eastward progradation of a paleo-shelf edge.

per part of the stratigraphic section, and into a central depocenter where it is associated with significant disturbance by magmatic rocks related to the still extant volcanic edifices of Ross Island and surrounding areas. Accordingly, it is interpreted to represent renewed rifting activity in the Victoria Land Basin (Cooper et al., 1987; Wilson, 1995; Salvini et al., 1997; Fielding et al., 2006; Henrys et al., 2007) and is termed "Terror Rift". The lower part of this interval comprises the mainly homoclinal section between the light green reflector and the dark green reflector which marks a major angular unconformity across the Victoria Land Basin (Figures 4-6). This interval, up to several hundred meters thick, had not been sampled by drilling prior to the AND-1B project (Naish et al., in press). Lithologies and vertical stacking patterns are therefore incompletely known. The homoclinical relationship of this interval with the underlying Passive Thermal Subsidence section suggests that it records continuation of Miocene sediment accumulation, and data from AND-1B (Naish et al., in press) suggest that it extended into the Upper Miocene ( 7.6 Ma).

Seismically, the lower part of the Terror Rift section is a sheet-like body in cross-section that passively thickens toward the central depocenter. Although some evidence of magmatic intrusion is evident within this interval, most such features are indicative of conduits that fed surface extrusive centers active during later forma- tion of the upper part of the Terror Rift succession (Henrys et al., 2007). The dominant seismic facies is again characterized by mainly parallel, continuous, moderate frequency, moderate to high amplitude events, with local evidence of clinoform geometries in both strike (Figure 4) and dip (Figure 6) lines on the Western Shelf and Slope. Intersections indicate progradation broadly eastward from the Transantarctic Mountains into the VLB.

In the absence of lithological ground-truth, the lower Terror Rift section is interpreted as a continuation of the shallow marine succession documented in CRP, with unknown but probably substantial influence from glacial advance-retreat cycles.

\subsection{Renewed Rifting (Terror Rift) interval, upper part (dark green reflector of Fielding et al., 2006 to surface)}

The dark green reflector marks a basin-wide unconformity, or in places a series of unconformities. Near the western margin of the Victoria Land Basin, this horizon is a marked angular discordance with angularity increasing westward (Figure 6). Eastward, the discordance decreases down the Western Slope such that into the depocenter the dark green horizon becomes a conformable surface. The upper Terror Rift section ( $7.6 \mathrm{Ma}$ to present, Upper Miocene to Recent) in crosssection is a wedge that tapers to the eastern and west- 


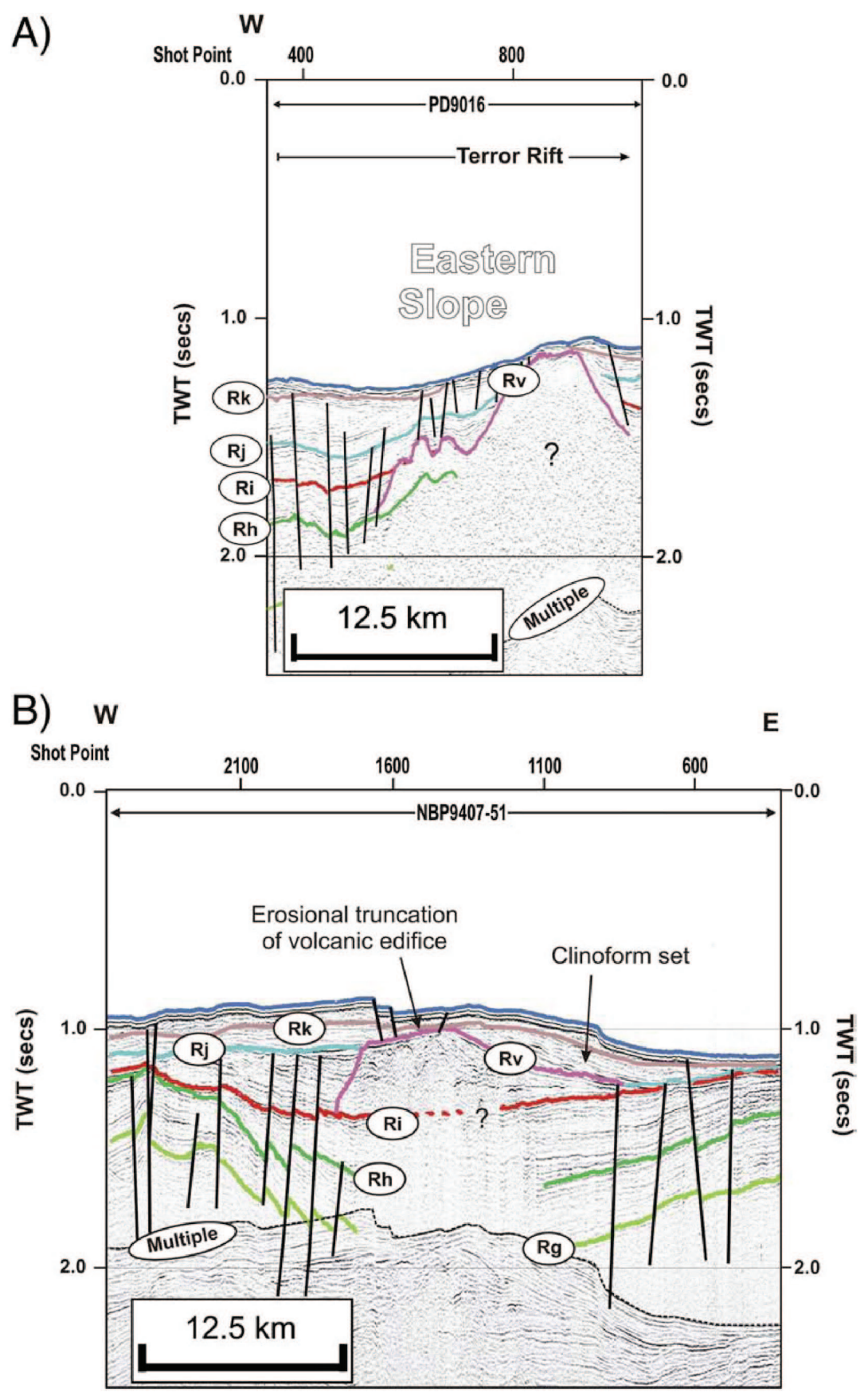

Figure 7. A) Part of seismic reflection line PD90-16 (Figure 1), showing stratal relationships among the Renewed Rifting phase in the basin depocenter. Note that inferred magmatic rocks appear to rest on the dark green $(\mathrm{Rh})$ reflector, suggesting that the volcanics in this area are no older than the dark green event in age. B) Part of seismic Reflection line NBP 9407-51, showing seismic stratigraphy and facies of the Renewed Rifting phase (light green - Rg to sea floor) in the central depocenter of the Victoria Land Basin. The segment shows an interpreted volcanic edifice (purple - Rv) constructed during the interval from the red (Ri) to turquoise (Rj) events, depression of the surface at the red (Ri) level due to flexure from emplacement of volcanic load, flexural moat fill on the western side of the edifice from red (Ri) to turquoise $(\mathrm{Rj})$, erosional truncation of this edifice at the turquoise level (arrowed), and resedimentation of eroded material as a large clinoform set (arrowed) off the eastern side of the edifice. See Table 1 for key to reflectors.

ern basin margins, and thickens to several hundred meters into the central depocenter where it is extensively intruded by and interbedded with magmatic rocks and cut by young faults (Figure 7). This interval has been sampled by drilling only in short, condensed intervals on the western basin margin, and latterly by AND-1B (Naish et al., in press).

The seismic section above the dark green reflector has been further divided into several sub-units, based on the recognition of two further, regionally extensive seis- 


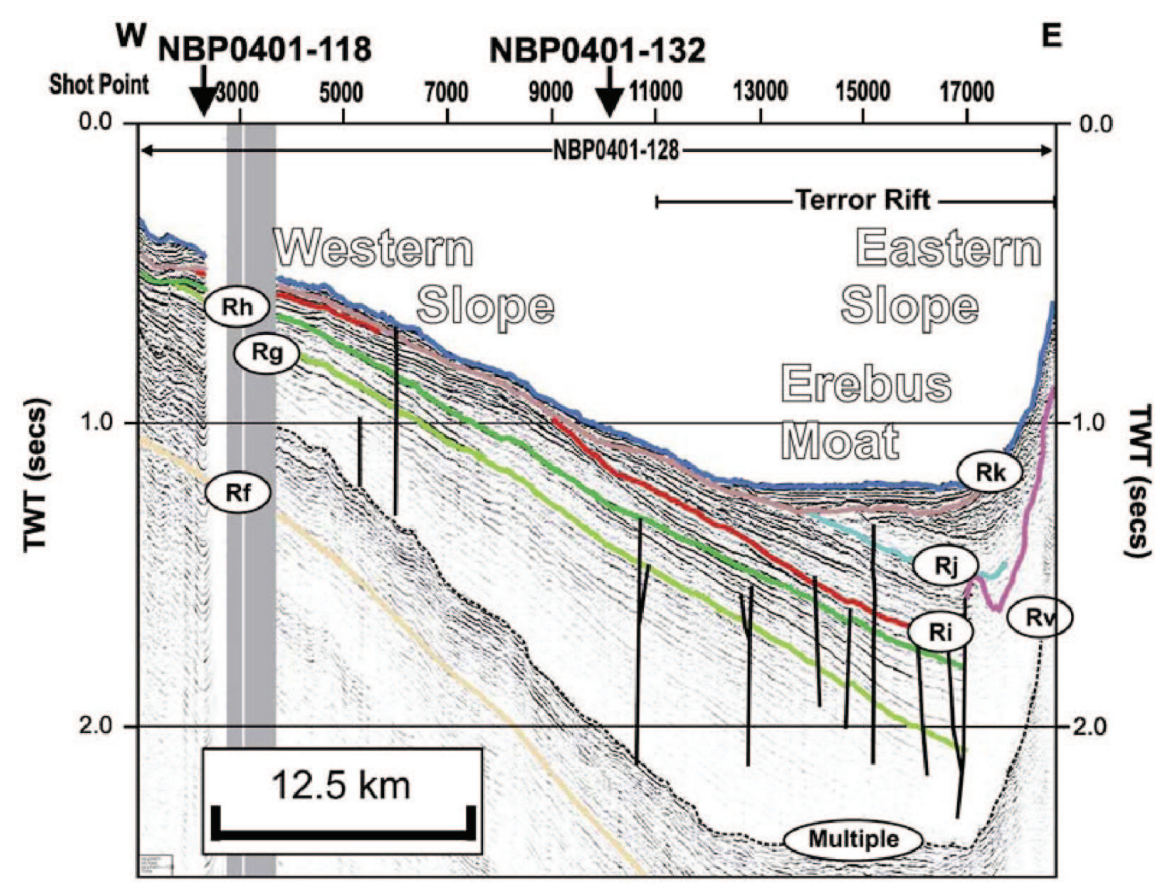

Figure 8. Part of seismic reflection line NBP0401-128, showing seismic stratigraphy and facies of the Renewed Rifting phase (light green - Rg to sea-floor) in the area of the Erebus moat, with adjacent Western and Eastern Slopes. This line emphasizes relationships in the youngest part of the section (post-turquoise: Rj), interpreted to have been strongly influenced by flexural subsidence associated with construction of Ross Island. Principal seismic facies are 1) irregular to chaotic, inclined, discontinuous, moderate to high amplitude events (slope deposits), 2) similar but low amplitude facies (slope deposits), and 3) flat-lying, parallel, concordant, continuous, moderate to high amplitude events (moat fill). See Table 1 for key to reflectors.

mic reflectors. They are, in ascending order, the red horizon and the turquoise horizon (which corresponds to reflector A1 of Horgan et al. (2005) from south of Hut Point Peninsula. Considerable attention has already been given to these intervals by Whittaker (2005), Horgan et al. (2005), and Naish et al. (2006), as they form the target intervals for the first ANDRILL campaign on McMurdo Ice Shelf (MIS). These authors have indeed recognized further seismic horizons that they have traced over discrete project areas. We have found some inconsistencies in the mapping of all these events, however, when they are traced outside the local project areas. For the purposes of this analysis, the upper Terror Rift section is divided into three sub-sections: a) from dark green to red, b) from red to turquoise, and c) from turquoise to the sea floor (Table 1).

The age of the dark green reflector is uncertain, but must be younger than $17 \mathrm{Ma}$. Volcanic rocks in a tongue extending from beneath White Island have been mapped at the dark green horizon in the MIS-1 seismic reflection data (Figure 1). If a new maximum age for White Island of 7.6 Ma (Cooper et al., 2007) is adopted, then this provides an approximate estimate for the age of the dark green reflector.
In proximal locations such as in CRP drillholes, the dark green reflector is truncated by younger horizons (Figures 4-6). The red reflector has been propagated into the area of CIROS- 1 and MSSTS- 1 , where it can be correlated to the litho- and biostratigraphy. In MSSTS-1, the red reflector correlates to about 20 mbsf in the core, close to a sample that contained Pliocene (4.6-4.0 Ma) microfossils and below which was barren of microfossils (Harwood et al., 2006; Harwood, unpublished data). Accordingly, the age of the red reflector can estimated at 4.6-4.0 Ma (and see Nash et al., in press). The turquoise reflector has been correlated into the Erebus Moat area where it represents the oldest horizon that is clearly influenced by flexural loading imposed by construction of the Ross Island volcanic edifices (e.g., Figure 8). Current geochronological data on the Ross Island volcanics (Esser et al., 2004), and the requirement for the load to exceed $\sim 2000 \mathrm{~km}^{3}$ before flexure will commence (Minshull and Charvis, 2001), suggest that this event corresponds to c. $2 \mathrm{Ma}$.

\subsubsection{Section from dark green to red reflectors}

In the western shelf area, the section overlying the dark green reflector is an eastward-thickening wedge 
that thins and is cut out by the red horizon onto the Roberts Ridge westward (Figure 6), but preserves an inner slope-shelf-shelf break-outer slope morphology to the east of Roberts Ridge. The section overlying the dark green reflector was evidently shed from earlier Cenozoic strata exposed during uplift and tilting of the western basin margin. Immediately overlying the dark green reflector on the inner slope immediately east of Roberts Ridge is a highly distinctive seismic unit. This unit has a lensoid cross-sectional geometry, pinching out both updip (where it onlaps the dark green horizon) and downdip (downlap onto dark green), and is internally characterized by a virtually reflection-free seismic fabric. Overlying strata downlap onto the upper part of this unit, but onlap its lower part (Figure 6), and successively re-establish the inner slope/shelf bathymetric profile with several kilometers eastward extension of, and offlap from the topset edge. Broad channel forms are preserved on some strike lines, mainly on the Western Shelf and upper Western Slope (e.g., Figure 4). Elsewhere on the Western Slope, clinoform sets were noted in the northern half of the strike line NBP0401-132 (Figure 5), with divergent dips indicating cross-sections through lobate, eastwardprograding systems. In the more basinward regions of the Western Slope and Erebus Moat, the principal seismic facies is a mainly parallel, concordant reflection character framed by moderate to high amplitude, moderate frequency, continuous reflections (Figures 5 \& 6). The red reflector in most data either onlaps assumed volcanic edifices of the basin-axial volcanic zone or passes beneath interpreted magmatic intervals (Figure 7A), but the dark green to red interval did not contribute to the construction of the Eastern Slope.

The reflection-free inner slope wedge (Figure 6) is similar in many respects to the slope lowstand wedges recognized by stratigraphers from continental margins worldwide (e.g., Catuneanu, 2006), and is interpreted to record the formation of a lithologically homogeneous mass of sediment on the inner slope following drawdown of relative sea-level coeval with or following the formation of the dark green reflector. The downlapping and onlapping relationships of overlying strata are consistent with stratigraphic patterns typical of a succeeding period of relative sea-level rise. The upward establishment of a topset platform in the proximal zone suggests massive relative sea-level rise, followed by filling of the resulting accommodation space during highstand. The eastward extension of the topset platform, at a level that defines the red reflector, suggests progradation of a nearshore, coarse clastic sediment wedge in a regime of limited accommodation, perhaps associated with late highstand. As such, the dark green to red in- terval could be considered as a single stratigraphic sequence (in the genetic sense), bounded by sequence boundaries recording drawdowns in relative sea-level. Furthermore, the magnitude of relative sea-level fluctuation evident from this interval (100-200 ms TWTT: $\sim 100-200 \mathrm{~m}$ ) suggests that it records a major event that is likely to have a geodynamic (rather than purely eustatic) origin. Given the correspondence between the dark green reflector and the evidence for significant interbedded magmatic products and significant thickening of the section above, it is likely that formation of the dark green event was in part due to tectonic processes.

\subsubsection{Section from red to turquoise}

The red reflector constitutes another major sequence boundary, as outlined above, and forms the base of a prominent interval of clinoform sets along the Western Shelf (Figures $5 \& 6$ ). This package is another eastwardthickening wedge in cross-section, as far east as the paleoshelf edge defined by the turquoise reflector. In places, this interval comprises a single, large-relief clinoform set $(<300 \mathrm{~ms}$ TWTT), whereas elsewhere it is composed of a series of smaller-amplitude clinoform sets. A further, possible lowstand wedge is developed in places at the base of the interval (Figure 6). Accumulation of the red-turquoise interval led to the construction of a broad, flat shelf that extended eastward some $25 \mathrm{~km}$ across the Western Slope (Figure 6). The turquoise reflector that marks the top of this interval defines the maximum eastward (basinward) extent of the paleo-shelf edge. Eastward of this inflection point, the red-turquoise interval thins down the Western Slope into the Erebus Moat region, where it comprises mainly a parallel, continuous, low-to-moderate amplitude and moderate frequency seismic facies noted above. In some lines, this interval then thickens further eastward into the Erebus Moat, where it displays a clinoform set geometry similar to that described above (e.g., Figure 8). In one area, c. $100 \mathrm{~km}$ north of Ross Island, depression of the surface at the level of the red event is evident below an upward-tapering section of chaotic to reflection-free facies (Figure 7B).

The red to turquoise interval is the youngest thick stratigraphic succession formed on the Western Shelf. The clinoform internal geometry suggests progradation of a thick terrigenous clastic succession, possibly via deltas, into standing water. The flat top surface, which extends to a paleo-shelf break at a significant distance basinward of the similar paleo-shelf break defined by the older red reflector (Figure 6), can be interpreted as the product of progradation forced by static or falling relative sea-level following filling of the available accommodation. This cross-sectional geometry, with 
a virtually horizontal shoreline or shelf edge trajectory through time, is characteristic of continental margin successions formed under forced regression during the early stages of relative sea-level drawdown. Geometrically, these clinoform sets resemble those interpreted as "subglacial deltas" by Anderson and Bartek (1992) elsewhere in the Ross Sea region, and the various terminoglacial delta and fan systems described by Lønne (1995, 2001), among others. In the case of the red-turquoise interval clinoforms, however, there is no direct evidence of glacial influence on their formation. The distal, baseof-slope section is interpreted to be basin floor turbidite and hemipelagic fallout deposits, whereas the distal clinoform sets are interpreted as recording progradation of deep marine slope fans. The depression of the red reflector beneath a discrete, reflection-free mass $100 \mathrm{~km}$ north of Ross Island is interpreted as the result of flexural loading of the surface beneath an imposed volcanic load, and the reflection-free mass as a volcanic edifice that was constructed during the interval represented between the red and turquoise reflectors (Figure 7B).

\subsubsection{Section from turquoise to sea-floor}

The turquoise reflector is the oldest stratigraphic horizon that can be related to flexural loading associated with construction of the Ross Island volcanic edifices. If this event was indeed formed by flexural loading imparted by emplacement of the Ross Island volcanoes (Kyle, 1990; Esser et al., 2004), then given the requirement that the load be significant $\left(\sim 2000 \mathrm{~km}^{3}\right)$ before the crust can be depressed, a reasonable estimate for the age of the turquoise reflector is $2 \mathrm{Ma}$ (see Figure 8 of Esser et al., 2004).

The turquoise horizon is a major unconformity, which strongly truncates older intervals westward onto the upper Western Slope and Western Shelf. The stratigraphic interval overlying the turquoise reflector is the youngest section recognized in the dataset. On the Western Shelf and Slope, it comprises a thin interval (typically $<100$ ms TWTT) characterized by moderate to high amplitude, high frequency discontinuous and irregular reflectors. This interval thickens downslope into the Erebus Moat, in places dramatically (Figure 8). There, the turquoise reflector also constitutes a major angular unconformity that truncates significant intervals of older strata, and downcuts progressively eastward into the Erebus Moat. The post-turquoise stratigraphic succession in the Erebus Moat can locally be further divided into several sub-units on the basis of further regionally traceable reflectors, some of which can be seen to cut out the turquoise and older horizons into the Erebus Moat. These intervals can also be correlated to the opposite side of Ross Island, where they form part of the target section for the MIS (AND-1B) drilling project (Horgan et al., 2005; Naish et al., 2006). Seismic facies in these sections comprise a) inclined, parallel to somewhat irregular, continuous, moderate to high amplitude and moderate to high frequency events, b) similar but low to moderate amplitude events, c) low-angle (shingled) clinoform sets associated with the former, and in the axis of the moat d) flat-lying, parallel, continuous moderate to high amplitude, moderate to high frequency reflectors (Figure 8). On the typically steeper Eastern Slope, these intervals comprise a) inclined, irregular to parallel, discontinuous, moderate to high amplitude and frequency reflections, b) similar, but low to moderate amplitude events, and c) inclined, chaotic to mounded, discontinuous, moderate amplitude and frequency events (Figure 8).

Further north, along trend from Ross Island, interesting relationships were noted in the post-turquoise section adjacent to an interpreted volcanic edifice (Figure 7B). The top of the volcano is evidently truncated by a planar erosion surface that has been mapped as the turquoise reflector, and a large-scale clinoform set is preserved downlapping onto turquoise east of the interpreted edifice, into deeper water. This represents a more substantial and steeper manifestation of the clinoforms noted above from further south within the Erebus Moat, and is in a similar structural setting.

The thickness distribution and seismic facies of the post-turquoise section are interpreted to be the product of mainly deep marine depositional processes under a regime of periodic and localized flexural loading of the lithosphere, associated with construction of the volcanic edifices of Ross Island (Horgan et al., 2005). The significant erosional relief on the turquoise reflector, and on some younger mapped horizons, suggests that flexural subsidence led to rapid steepening and erosional reworking of the lower Western Slope, and establishment and repeated reactivation of the Erebus Moat depocenter. Sedimentation was initially via progradation of slope systems, including locally some systems with clinoform geometry. Sediment evidently accumulated via episodic introduction of both fine- and coarse-grained mass flows and slope failures. Seismic facies in many respects resemble those described from deep marine, base-of-slope systems worldwide (e.g., Posamentier and Kolla, 2003; Fugelli and Olsen, 2005). The youngest part of the succession is a mainly flat-lying basin fill that is interpreted to have been the product mainly of turbidites and hemipelagic sediment fallout. This latter section resembles in many respects the stratigraphy of Neogene intraslope ponded basins on 
the Gulf of Mexico continental slope (e.g., Prather et al., 1998; Beaubouef and Friedmann, 2000), in which rapid subsidence in discrete areas is driven by subsurface salt withdrawal. Slope systems, presumably composed of mass flow deposits, comprise the narrow and relatively steep Eastern Slope. Further updip on the Western Slope, in contrast, the post-turquoise section is very thin, suggesting that sediment dispersal from the western basin margin had all but ceased by the time of the turquoise reflector $(\sim 2 \mathrm{Ma})$.

The large-scale clinoform set noted adjacent to the erosionally truncated volcanic edifice to the north of Ross Island may represent a subglacial or terminoglacial delta/ fan system (cf. Lønne, 1995) supplied by sediment delivered by glacial erosion of the moribund and partly buried volcano (Figure 7B). Given the distal location of this feature with respect to the Transantarctic Mountains, this may record increasing glacial incursions into the basin in post-turquoise horizon times, and potentially a different direction of glacial advance and sediment dispersal into the basin depocenter (?from the south).

\section{Synthesis}

Our previous work has established a five phase geological history for the western Victoria Land Basin, based primarily on tectonic changes (Table 1). In the preceding discourse, we have summarized the principal external geometries and internal facies characteristics of each major stratigraphic interval as defined by this framework. Major changes in the external geometry of seismic intervals define the basin phases, and are interpreted to reflect tectonic drivers. But this analysis has also shown that changes in internal seismic facies also coincide with these boundaries. The most profound changes in the seismic facies assemblage occur at the dark green reflector (boundary between the lower and upper Terror Rift successions), and at the turquoise reflector (onset of flexural loading associated with emplacement of Ross Island volcanic pile). Although this younger part of the stratigraphic succession has not yet been fully characterized, the older section is continuously sampled by the CRP and CIROS drillholes, and it is possible to evaluate there whether tectonically-defined boundaries show any relationship with climatic thresholds inferred from cores. Figure 9 shows that there is indeed a strong coincidence between the boundaries of basin-forming phases and the timing of major interpreted climatic shifts for those horizons that have been sampled by drilling. This in turn suggests that other, as yet undrilled, key stratigraphic surfaces may also be associated with climatic shifts, and indicates a strong connection between tectonic events and environmental change through the Cenozoic in eastern Antarctica. In order to summarize these relationships, the succession is reviewed below in terms of seismic facies assemblages and their interpretation.

The Early Rift phase is characterized by a thick succession of mainly coarse-grained lithologies that largely lacks evidence of cyclicity. Lithofacies and seismic facies together suggest progradation of coarse-grained fan and delta systems into progressively opening half-graben infra-basins. In the Cape Roberts section, the structural interpretation of USGS seismic line L2-AN-84-403/404 indicates that these systems were shed down a hangingwall slope towards a depocenter located near an active extensional fault. Available data suggest that sediments were accumulated in shallow water throughout this interval, indicating a ready supply of terrigenous clastic sediment was able to balance the rapid rate of subsidence (sediment-balanced system of Ravnås and Steel, 1998). Provenance data from the gravel and sand fractions of the succession confirm the Transantarctic Mountains as the dominant source of this sediment (Barrett and Ricci, 2000). Lack of data preclude the assessment of how regionally extensive this pattern is.

The Main Rift phase is characterized by a more parallel, continuous reflection character, with a gradual eastward expansion of accommodation associated with the transfer of the depocenter to a more basin-central location. This has been interpreted in terms of repeated cycles of shallow marine to coastal facies, with a cyclical motif becoming increasingly recognizable up-section. Cyclicity has been interpreted to derive from glacial advance-retreat patterns and associated eustatic sea-level fluctuations, while the thickness of cycles has been attributed primarily to changes in tectonically-driven accommodation. This pattern is similar to the stacking patterns of other nearshore marine successions formed under comparable tectonic and climatic regimes (e.g., Plio-Pleistocene of the Wanganui Basin, New Zealand: Naish et al., 1998; Saul et al., 1999; Miocene of the Chesapeake Group, eastern USA: Kidwell, 1997), and with the architecture of coeval strata further east in the West Antarctic Rift by Bartek et al. (1997). The local preservation of clinoform sets suggests preservation of the downlapping bedding surface architecture predicted by sequence stratigraphic models and by those described in the above examples. The local occurrence of channel forms is interpreted as due to formation and preservation of subglacial or proximal proglacial channels during glacial-advance-retreat cycles. Seismic data show a lack of evidence for positive depositional topography 


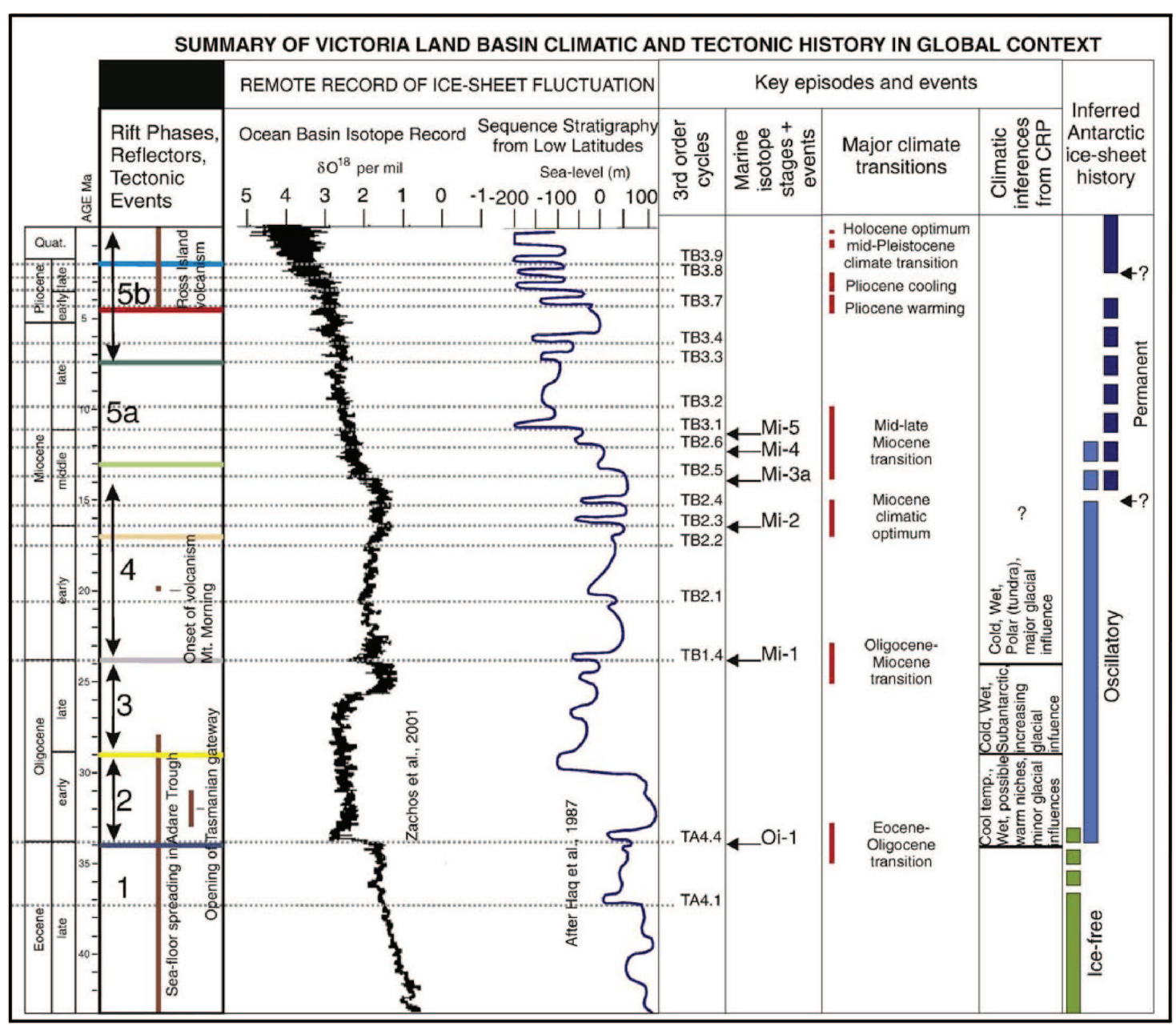

Figure 9. Summary of the principal known elements of Victoria Land Basin tectonic and climatic history, with data from the Cape Roberts Project and the present study in a global context. Rift history phases and key seismic reflectors are as in Table 1 . The beige reflector at 17 Ma represents the youngest pre-Pliocene strata intersected by Cape Roberts Project drilling.

such as might have arisen from the formation of substantial moraine ridges. Thus, the depositional model of Dunbar et al. (this volume) is preferred to the models of Powell et al. (2000), Powell and Cooper (2002), and Hambrey et al. (2002), which predict a stratigraphic cross-section punctuated by abundant, high-profile, morainal banks. A simple cross-sectional model incorporating the seismic facies noted herein from the Main Rift and Thermal Subsidence phases in dip lines on the Western Shelf and upper Western Slope, is presented in Figure 10. The glacial character of the sediments becomes progressively more apparent through this interval. This long term cooling trend is consistent with increased physical weathering indicated by clays (Ehrmann et al., 2005) and various paleontological and other proxies (Barrett, in press). An abrupt change in sequence character at the top of the Main Rift interval may have been associated with the Mi- 1 climatic deterioration, in addition to a change in subsidence regime.
The Passive Thermal Subsidence phase is again characterized by parallel, mainly concordant reflections, but contains more abundance for incision of channel scours at sequence boundaries, and of clinoform sets within sequences. Lithofacies data from drillcores indicate a progressively more austere climatic regime through this time, but subsidence analysis (Wilson et al., submitted for publication) also indicates a substantially lower rate of subsidence as is expected for a postrift, thermal subsidence regime. Accordingly, the changes in seismic facies are attributed herein primarily to the lower rate of subsidence preferentially forming and preserving channels and clinoform sets within the stratigraphy.

The lower part of the Renewed Rifting (lower Terror Rift) phase is seismically similar to, and homoclinal with, the underlying section, and is interpreted to record similar conditions. The upper part of this section, however, shows substantial changes both in cross-sectional geometry and internal seismic facies that are worthy of review. 

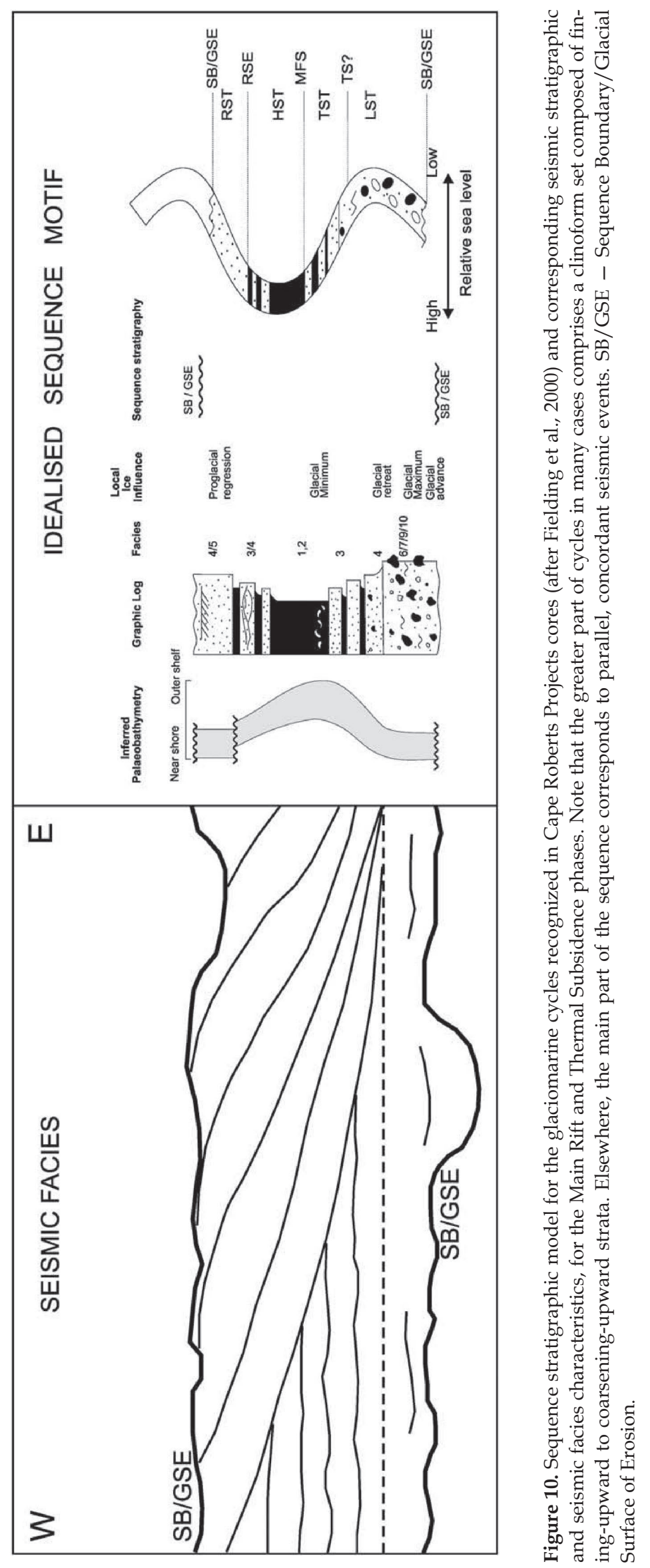
The dark green reflector (?7.6 Ma) clearly records a substantial tectonic upheaval along the western margin of the basin, causing progressive uplift of the proximal section and presumably a depositional hiatus. Given the evidence for substantial uplift of the proximal region of the basin and adjacent Transantarctic Mountains, an analogy with the rift shoulder uplift process described by Japsen et al. (2006) is considered reasonable.

Erosion of material from the western margin provided sediment for renewed sediment accumulation, initially in a single, thick, seismically defined sequence with a prominent lowstand wedge and displaying subsequent downlapping and onlapping relationships onto this body. An alternative interpretation of the acoustically bland wedges above the dark green horizon is that they record lobes of glacial diamictite in transverse section, similar to the interpreted "till lobes" of Anderson and Bartek (1992), but this is considered less likely given their location on the lower part of a slope. The substantial vertical interval of this sequence implies a major rise in relative sea-level, and comparison with the eustatic curve of Haq et al. (1987) suggests that it may coincide with a massive rise in sea-level $(\sim 100 \mathrm{~m})$ between 6 and 5 Ma that preceded Pliocene climatic deterioration.

The red event (Bclino) also records a major change in seismic facies, marking the base of an interval of largescale clinoform sets. Relationships between the red horizon and inferred volcanics (e.g., Figure 7A) and microfossil data suggest that the red reflector may be $\mathrm{c}$. 4.6-4.0 Ma in age. The red-turquoise interval is interpreted as reflecting a further interval of terrigenous clastic sediment input to the basin, and the last significant episode of sediment dispersed from the western basin margin. The clinoform geometries are similar to those recorded by Anderson and Bartek (1992), and interpreted as "subglacial deltas". This interpretation is plausible for the VLB clinoforms, but given the planar topset and lack of evidence for glacial scouring in this section, a broader shelf or shelf-margin delta interpretation also seems tenable.

The uppermost part of the section, above the turquoise reflector, was formed during a period of little to no sediment input from the western basin margin. In this interval, thickness distribution patterns and seismic facies indicate that sedimentation was dominated by downslope, mass wasting and basin floor filling in deep water, caused by flexural loading and formation of the Erebus Moat. This suggests that supply of voluminous terrigenous clastic sediment was shut off at c. $2 \mathrm{Ma}$, since the turquoise reflector must postdate construction of the Ross Island volcanoes (Esser et al., 2004). Most of the erosional relief evident at the modern sea-floor, such as the Mackay Sea Valley and other valleys offshore from the Ferrar valley and New Harbor, and near-surface channel fills such as are found near CIROS-1, is interpreted to postdate the turquoise reflector, from crosscutting relationships. This suggests that the shutdown in clastic sediment supply noted above was accompanied by a regime of profound erosional scouring of the Western Slope of the VLB and elsewhere. Cross-sections through clinoform sets in seismic data suggest that the major direction of sediment dispersal during this period may have been basin-axial, i.e., from the south, while the change in cross-sectional seismic geometry suggests that deepening of the depositional surface and change to the present-day ramp sea-floor physiography may have taken place at turquoise reflector time.

\section{Conclusions}

Based on integration of regional seismic reflection surveys with available drillcore data, the stratigraphic succession of the western Victoria Land Basin in McMurdo Sound, Antarctica, has been resolved into a series of intervals each reflecting changes in basin-forming tectonic processes. The Early Rift and subsequent Main Rift phases (latest Eocene to Oligocene) were characterized by accumulation of mainly coarse-grained fan and deltaic to shallow marine successions, initially in faultbounded sub-basins but later in a larger, linked basin system as the rift expanded. These successions became increasingly cyclical up-section, and were arranged in genetic sequences that were driven by advance and retreat of glaciers across the western part of the basin. A subsequent phase of slower, Passive Thermal Subsidence (Miocene) resulted in a similar, sheet-like cross-sectional sequence geometry, but greater preservation of erosional channel forms and clinoforms.

Renewed rifting activity associated with formation of the Terror Rift (Miocene to present) produced at first little change in seismic facies, but after uplift and erosion at the dark green reflector, a complete change in seismic character was effected. A series of substantial clinoform sets records the last period of significant terrigenous clastic supply to the western part of the basin. The turquoise reflector that marks the top of this clinoform section also marks the onset of flexural loading associated with emplacement of the Ross Island volcanic pile. The overlying interval shows a shift in the locus of sedimentation, with pronounced erosion of the Western Shelf and Slope, and redeposition of sediment by mass movement processes into the flexural moats formed around Ross Island and other volcanic edifices. Sediment sup- 
ply to the basin was significantly reduced and dispersal may have been dominantly basin-axial, from the south. Deepening of the sediment-water interface and modification of sea-floor physiography to the present ramp configuration may have happened at the time of the turquoise reflector. This event, likely to be $\sim 2 \mathrm{Ma}$, also provides a maximum age constraint on the change from a wet polar to a dry, cold polar environment in this region. An age of $\sim 2 \mathrm{Ma}$ for the transition to the current cold, polar environment is broadly consistent with other recent research from the margins of Antarctica (e.g., Hambrey and McKelvey, 2000; Rebesco et al., 2006).

Despite the manifest glacial influence on sedimentation and stratigraphic stacking patterns within the western VLB section (or at least, the latest Eocene to Lower Miocene part that has been cored to date), the cross-sectional geometry of broad intervals, individual sequences and seismic facies within sequences are believed to owe their character more to the subsidence pattern that characterizes each basin phase. This suggests that it would be unwise to interpret drilling records solely in terms of climatic history, in isolation from the regional context of the succession. This pattern is also consistent with recent research on rift basins, including glaciated rift basins, that suggests that the overriding control on facies architecture is tectonic (Eyles, 1993; Ravnås and Steel, 1998; Gawthorpe and Leeder, 2000). Nonetheless, the coincidences between key stratigraphic surfaces and evidence for major environmental change through the Cenozoic succession in the southern Victoria Land Basin suggests some causal link between tectonic and climatic drivers through this time.

\section{Acknowledgments}

We acknowledge the Cape Roberts Drilling and Science Teams for their efforts in acquiring and characterizing the drillcores from CRP holes. CRF's participation in the Cape Roberts Project was supported by two out-of-cycle research grants from the Australian Research Council. SAH, JW, and TRN acknowledge support from the Royal Society of New Zealand Marsden Fund. TJW's participation in the Cape Roberts Project was supported by the National Science Foundation under grant OPP-9527394. Continued work by TJW on the McMurdo Sound basin framework has been supported by NSF-OPP-0313974. We thank Richard Levy for allowing use and modification of a diagram from the MIS SLIP, and David Harwood for sharing unpublished micropaleontological data. Two anonymous referees and G. Wilson provided constructive reviews of the submitted manuscript.

\section{References}

Anderson and Bartek, 1992 J. B. Anderson and L. R. Bartek, Cenozoic glacial history of the Ross Sea revealed by intermediate resolution seismic reflection data combined with drill site information. In J. P. Kennett and D. A. Warnke, Editors, The Antarctic Paleoenvironment: A Perspective on Global Change, Part 1, Antarctic Research Series vol. 56, American Geophysical Union, Washington, D. C. (1992), pp. 231-263.

Barrett, $1986>$ P. J. Barrett, Editor, Antarctic Cenozoic History from the MSSTS-1 Borehole, New Zealand Department of Scientific and Industrial Research Bulletin 237 (1986), pp. 1-174.

Barrett, 1989 P. J. Barrett, Editor, Antarctic Cenozoic History from the CIROS-1 Borehole, New Zealand Department of Scientific and Industrial Research Bulletin 245 (1989), pp. 1-251.

Barrett, 2007 P. J. Barrett, Cenozoic climate and sea level history from glacimarine strata off the Victoria Land coast, Cape Roberts Project, Antarctica. In M. J. Hambrey, P. Christoffersen, N. F. Glasser, and B. Hubbart, Editors, Glacial Processes and Products. International Association of Sedimentologists Special Publication 39 (2007), pp. 259-287.

Barrett and Hambrey, 1992 P. J. Barrett and M. J. Hambrey, PlioPleistocene sedimentation in Ferrar Fjord, Antarctica, Sedimentology 39 (1992), pp. 109-123.

Barrett and Ricci, 2000 In P. J. Barrett and C. A. Ricci, Editors, Studies from the Cape Roberts Project, Ross Sea, Antarctica: Scientific Results of CRP-2/2A, Terra Antartica 7 (2000), pp. 211-654.

Barrett et al., 1995 P. J. Barrett, S. A. Henrys, L. R. Bartek, G. Brancolini, M. Busetti, F. J. Davey, M. J. Hannah, and A. R. Pyne, Geology of the margin of the Victoria Land Basin off Cape Roberts, southwest Ross Sea. In A. K. Cooper, P. F. Barker, and G. Brancolini, Editors, Geology and Seismic Stratigraphy of the Antarctic Margin, Antarctic Research Series 68, American Geophysical Union, Washington, D. C. (1995), pp. 183-207.

Bartek et al., 1996 L. R. Bartek, S. A. Henrys, J. B. Anderson, and P. J. Barrett, Seismic stratigraphy of McMurdo Sound, Antarctica: Implications for glacially influenced early Cenozoic eustatic change?, Marine Geology 130 (1996), pp. 79-98.

Bartek et al., 1997 L. R. Bartek, J. R. L. Andersen, and T. A. Oneacre, Substrate control on distribution of subglacial and glaciomarine seismic facies based on stochastic models of glacial seismic facies deposition on the Ross Sea continental margin, Antarctica, Marine Geology 143 (1997), pp. 223-262.

Beaubouef and Friedmann, $2000 \triangleright$ R. T. Beaubouef and S. J. Friedmann, High resolution seismic/sequence stratigraphic framework for the evolution of Pleistocene intra slope basins, western Gulf of Mexico: Depositional models and reservoir analogs. In P. Weimer, R. M. Slatt, J. Coleman, N. C. Rosen, H. Nelson, A. H. Bouma, M. J. Styzen, and D. T. Lawrence, editors, Deep-Water Reservoirs of the World. Gulf Coast Section SEPM, 20th Annual Bob Perkins Research Conference, Houston, Texas (2000), pp. 40-60.

Blikra and Nemec, 1998 L. H. Blikra and W. Nemec, Postglacial colluvium in western Norway: Depositional processes, facies and palaeoclimatic record, Sedimentology 45 (1998), pp. 909-959.

Bohaty and Harwood, $2000 \longrightarrow$ S. M. Bohaty and D. M. Harwood, Ebridian and silicoflagellate biostratigraphy from Eocene McMurdo erratics and the Southern Ocean. In J. D. Stilwell and R. M. Feldmann, Editors, Paleobiology and Paleoenvironments of Eocene rocks, McMurdo Sound, East Antarctica, Antarctic Research Series 76, American Geophysical Union, Washington, D. C. (2000), pp. 99-159.

Brancolini et al., 1995a $>$ G. Brancolini, A. K. Cooper, and F. Coren, Seismic facies and glacial history in the Western Ross Sea (Antarctica). In A. K. Cooper, P. F. Barker, and G. Brancolini, Editors, Geology and Seismic Stratigraphy of the Antarctic Margin, Antarctic Research Series 68, American Geophysical Union, Washington, D. C. (1995), pp. 209-233. 
Brancolini et al., 1995b G. Brancolini, M. Busetti, A. Marchetti, L. De Santis, C. Zanolla, A. K. Cooper, G. R. Caochrane, I. Zayatz, V. Belyaev, M. Knyazev, O. Vinnikovskaya, F. J. Davey, and K. Hinz, Descriptive text for the seismic stratigraphic atlas of the Ross Sea, Antarctica. In A. K. Cooper, P. F. Barker, and G. Brancolini, Editors, Geology and Seismic Stratigraphy of the Antarctic Margin, Antarctic Research Series 68, American Geophysical Union, Washington, D. C. (1995), pp. A271-A286.

Bucker et al., $1998 \longrightarrow$ C. J. Bucker, S. A. Henrys, and T. Wonik, Revision of the Cenozoic seismic velocity structure of the CIROS-1 drillhole, Antarctica, and implications for further drilling off Cape Roberts, Terra Antartica 5 (1998), pp. 281-289.

Cape Roberts Science Team, 1998 Cape Roberts Science Team, Initial report on CRP-1, Cape Roberts Project, Antarctica, Terra Antartica 5 (1998), pp. 1-187.

Cape Roberts Science Team, 1999 Cape Roberts Science Team, Studies from the Cape Roberts Project, Ross Sea, Antarctica: Initial report on CRP-2/2A, Terra Antartica 6 (1999), pp. 1-173.

Cape Roberts Science Team, 2000 Cape Roberts Science Team, Studies from the Cape Roberts Project, Ross Sea, Antarctica: Initial report on CRP-3, Terra Antartcia 7 (2000), pp. 1-209.

Catuneanu, 2006 O. Catuneanu, Principles of Sequence Stratigraphy, Elsevier, Amsterdam (2006) 375 pp. .

Cooper et al., 1987 A. K. Cooper, F. J. Davey, and J. C. Behrendt, Seismic stratigraphy and structure of the Victoria Land Basin, Western Ross Sea, Antarctica. In A. K. Cooper and F. J. Davey, Editors, The Antarctic Continental Margin: Geology and Geophysics of the Western Ross Sea. Circum-Pacific Council for Energy and Mineral Resources, Earth Sciences Series, 5B, Houston, Texas (1987), pp. 27-65.

Cooper et al., 2007 A. F. Cooper, L. J. Adam, R. F. Coulter, G. N. Eby, and W. C. McIntosh, Geology, geochronology and geochemistry of a basanitic volcano, White Island, Ross Sea, Antartica, Journal of Volcanology and Geothermal Research 165 (2007), pp. 189-216.

Dadisman et al., 1987 S. V. Dadisman, H. F. Ryan, and D. M. Mann, Recording and processing procedures for multichannel seismicreflection data collected in the western Ross Sea, Antarctica, The Antarctic Continental Margin: Geology and Geophysics of the Western Ross Sea. Circum-Pacific Council for Energy and Mineral Resources, Earth Sciences Series 5b, Houston, Texas (1987), pp. 17-26.

Davey and Brancolini, $1995>$ F. J. Davey and G. Brancolini, The Late Mesozoic and Cenozoic structural setting of the Ross Sea region. In A. K. Cooper, P. F. Barker, and G. Brancolini, Editors, Geology and Seismic Stratigraphy of the Antarctic Margin, Antarctic Research Series 68, American Geophysical Union, Washington, D. C. (1995), pp. 167-182.

Dunbar et al., 2008 G. B. Dunbar, T. Naish, P. J. Barrett, C. R. Fielding, and R. D. Powell, Constraining the amplitude of late Oligocene bathymetric changes in Western Ross Sea during orbitally-induced oscillations in the East Antarctic Ice Sheet: (1) Implications for glacimarine sequence stratigraphic models., Palaeogeography, Palaeoclimatology, Paleoecology 260 (2008), pp. 50-65.

Ehrmann et al., 2005 W. Ehrmann, M. Setti, and L. Marinoni, Clay Minerals in Cenozoic Sediments Off Cape Roberts (McMurdo Sound, Antarctica) Reveal Palaeoclimatic History, Palaeogeography, Palaeoclimatology, Palaeoecology 229 (2005), pp. 187-211.

Esser et al., $2004 \longrightarrow$ R. E. Esser, P. R. Kyle, and W. C. MacIntosh, ${ }^{40} \mathrm{Ar} /{ }^{39} \mathrm{Ar}$ dating of the eruptive history of Mount Erebus, Antarctica: Volcano evolution, Bulletin of Volcanology 66 (2004), pp. 671-686.

Eyles, 1993 N. Eyles, Earth's glacial record and its tectonic setting, Earth-Science Reviews 35 (1993), pp. 1-248.

Fielding et al., $1998-$ C. R. Fielding, K. J. Woolfe, J. A. Howe, and M. A. Lavelle, Sequence stratigraphic analysis of CRP-1, Cape Roberts Project, McMurdo Sound, Antarctica, Terra Antartica 5 (1998), pp. 353-361.

Fielding et al., $2000 \triangleright$ C. R. Fielding, T. R. Naish, K. J. Woolfe, and M. A. Lavelle, Facies analysis and sequence stratigraphy of CRP-
2/2A, Victoria Land Basin, Antarctica, Terra Antartica 7 (2000), pp. 323-338.

Fielding et al., $2001>$ C. R. Fielding, T. R. Naish, and K. J. Woolfe, Facies architecture of the CRP-3 drillhole, Victoria Land Basin, Antarctica, Terra Antartica 8 (2001), pp. 217-224.

Fielding et al., $2006 \checkmark$ C. R. Fielding, S. A. Henrys, and T. J. Wilson, Rift history of the western Victoria Land Basin: A new perspective based on integration of cores with seismic reflection data. In D. K. Futterer, D. Damaske, G. Kleinschmidt, H. Miller and F. Tessensohn, Editors, Antarctica: Contributions to Global Earth Sciences, Springer-Verlag, Berlin (2006), pp. 309-318.

Fugelli and Olsen, 2005 E. M. G. Fugelli and T. R. Olsen, Screening for deep-marine reservoirs in frontier basins: Part 1, examples from offshore mid-Norway, American Association of Petroleum Geologists Bulletin 89 (2005), pp. 853-882.

Gawthorpe and Leeder, $2000>$ R. L. Gawthorpe and M. R. Leeder, Tectono-sedimentary evolution of active extensional basins, Basin Research 12 (2000), pp. 195-218.

Hambrey and McKelvey, $2000-$ M. J. Hambrey and B. C. McKelvey, Neogene fluctuations of the East Antarctic Ice Sheet: Stratigraphic evidence from the Lambert Glacier region, Geology 28 (2000), pp. 887-890.

Hambrey et al., 2002 M. J. Hambrey, P. J. Barrett, and R. D. Powell, Late Oligocene and early Miocene glacimarine sedimentation in the SW Ross Sea, Antarctica: The record from offshore drilling. In J. A. Dowdeswell and C. O' Cofaigh, Editors, Glacier-influenced Sedimentation on High-latitude Continental Margins, Geological Society of London Special Publication 203 (2002), pp. 105-128.

Hamilton et al., 2001 R. J. Hamilton, B. P. Luyendyk, C. C. Sorlien, and L. R. Bartek, Cenozoic tectonics of the Cape Roberts Rift Basin and Transantarctic Mountain Front, southwestern Ross Sea, Antarctica, Tectonics 20 (2001), pp. 325-342.

Hannah et al., 1997 M. J. Hannah, M. B. Cita, R. Coccioni, and S. Monechi, The Eocene/Oligocene boundary at $70^{\circ}$ South, McMurdo Sound, Antarctica, Terra Antartica 4 (1997), pp. 79-87.

Haq et al., 1987 B. U. Haq, J. Hardenbol, and P. R. Vail, Chronology of fluctuating sea levels since the Triassic, Science 235 (1987), pp. 1156-1167.

Harwood et al., 2006 D. M. Harwood, F. Florindo, R. H. Levy, C. R. Fielding, S. F. Pekar, M. A. Speece, and SMS Science Team, ANDRILL Southern McMurdo sound scientific prospectus, ANDRILL Contribution 5, Science Management Office, University of NebraskaLincoln (2006), pp. 1-29.

Hayes and Frakes, 1975 D. E. Hayes and L. A. Frakes, General synthesis: Deep Sea Drilling Project 28, Initial Reports of the Deep Sea Drilling Project 28 (1975), pp. 919-942.

Henrys et al., 2000 S. A. Henrys, C. J. Bucker, L. R. Bartek, S. Bannister, F. Niessen, and T. Wonik, Correlation of seismic reflectors with CRP-2/2A, Victoria Land Basin, Antarctica, Terra Antartica 7 (2000), pp. 221-230.

Henrys et al., 2001 S. A. Henrys, C. J. Bucker, F. Niessen, and L. R. Bartek, Correlation of seismic reflectors with the CRP-3 drillhole, Victoria Land Basin, Antarctica, Terra Antartica 8 (2001), pp. 127-136.

Henrys et al., 2007 S. A. Henrys, T. Wilson, J. M. Whittaker, C. Fielding, J. Hall, and T. Naish, Tectonic history of mid-Miocene to present southern Victoria Land Basin, inferred from seismic stratigraphy in McMurdo Sound, Antarctica. In A. K. Cooper, C. R. Raymond, et al. (eds.), Antarctica: A Keystone in a Changing World - Online Proceedings of the 10th International Symposium on Antarctic Earth Sciences, US Geological Survey Open-File Report 20071047, Short Research Paper 049, 4p., 2007. doi:10.3133/of20071047.srp049

Horgan et al., $2005>$ H. Horgan, T. Naish, S. Bannister, N. Balfour, and G. Wilson, Seismic stratigraphy of the Plio-Pleistocene Ross Island flexural moat-fill: A prognosis for ANDRILL Program drilling beneath McMurdo-Ross Ice Shelf, Global and Planetary Change 45 (2005), pp. 83-97. 
Japsen et al., $2006 \triangleright$ P. Japsen, J. M. Bonow, P. F. Green, J. A. Chalmers, and K. Lidmar-Bergstrom, Elevated, passive continental margins: Long-term highs or Neogene uplifts? New evidence from West Greenland, Earth and Planetary Sciences Letters 248 (2006), pp. 330-339.

Kidwell, 1997 S. M. Kidwell, Anatomy of extremely thin marine sequences landward of a passive margin hinge-zone: Neogene Calvert Cliffs succession, Maryland, USA, Journal of Sedimentary Research 67 (1997), pp. 322-340.

Kyle, 1990 P. R. Kyle, McMurdo Volcanic Group - Western Ross Embayment: Introduction. In W. E. LeMasurier and J. W. Thomson, Editors, Volcanoes of the Antarctic Plate and Southern Oceans, Antarctic Research Series 48, American Geophysical Union, Washington, D. C. (1990), pp. 19-25.

Lønne, 1995 I. Lønne, Sedimentary facies and depositional architecture of ice-contact glaciomarine systems, Sedimentary Geology 98 (1995), pp. 13-43.

Lønne, 2001 I. Lønne, Sedimentary architecture and dynamic stratigraphy of a marine ice-contact system, Journal of Sedimentary Research 71 (2001), pp. 922-943.

McGinnis, 1981 L. D. McGinnis, Editor, Dry Valley Drilling Project, Antarctic Research Series vol. 33, American Geophysical Union, Washington, D. C. (1981) 465 pp.

Miller et al., 1991 K. G. Miller, J. D. Wright, and R. G. Fairbanks, Unlocking the Ice House: Oligocene-Miocene oxygen isotopes, eustasy, and margin erosion, Journal of Geophysical Research 96 (1991), pp. 6829-6848.

Minshull and Charvis, 2001 T. A. Minshull and P. Charvis, Ocean island densities and models of lithospheric flexure, Geophysical Journal International 145 (2001), pp. 731-739.

Naish and Wilson, $2008 \rightarrow$ T. R. Naish and G. S Wilson, Late Oligocene, glacial-interglacial climate and sea-level cycles from a shallow-marine record adjacent to the East Antarctic Ice Sheet, Cape Roberts, Western Ross Sea, Palaeogeography, Palaeoclimatology, Palaeoecology 260 (2008), pp. 66-76; doi: 10.1016/j.palaeo.2007.08.021

Naish et al., 1998 T. R. Naish, S. T. Abbott, B. V. Alloway, A. G. Beu, R. M. Carter, A. R. Edwards, T. D. Journeaux, P. J. J. Kamp, B. J. Pillans, G. Saul, and K. J. Woolfe, Astronomical calibration of a southern hemisphere Plio-Pleistocene reference section, Wanganui Basin, New Zealand, Quaternary Science Reviews 17 (1998), pp. 695-710.

Naish et al., 2001 T. R. Naish, K. J. Woolfe, G. S. Wilson, C. Atkins, P. J. Barrett, S. M. Bohaty, C. Bucker, M. Claps, F. Davey, G. Dunbar, A. G. Dunn, C. R. Fielding, F. Florindo, M. Hannah, D. M. Harwood, D. Watkins, S. Henrys, L. Krissek, M. A. Lavelle, J. van der Meer, W. C. McIntosh, F. Niessen, S. Passchier, R. D. Powell, A. P. Roberts, A. P. Sagnotti, R. P. Scherer, C. P. Strong, F. Talarico, K. L. Verosub, P. -N. Webb, and T. Wonik, Orbitally induced oscillations in the East Antarctic Ice Sheet: direct evidence from the Cape Roberts Drilling Project, Nature 413 (2001), pp. 719-723.

Naish et al., 2006 T. R. Naish, R. D. Powell, P. J. Barrett, H. Horgan, G. Dunbar, G. Wilson, R. Levy, N. Robinson, L. Carter, A. Pyne, F. Niessen, S. Bannister, N. Balfour, D. Damaske, S. Henrys, P. Kyle and T. Wilson, ANDRILL McMurdo Ice Shelf Project Scientific Prospectus, ANDRILL Contribution 4, Science Management Office, University of Nebraska-Lincoln (2006), pp. 1-18.

Naish et al., in press T. Naish, R. Powell, R. Levy, S. Henrys, L. Krissek, F. Niessen, M. Pompilio, R. Scherer, G. Wilson, and ANDRILL-MIS Science Team, Synthesis of the Initial Scientific Results of the MIS Project (AND-1B Core), Victoria Land Basin, Antarctica. Terra Antarctica 14; in press.
Posamentier and Kolla, 2003 - H. W. Posamentier and V. Kolla, Seismic geomorphology and stratigraphy of depositional elements in deep-water settings, Journal of Sedimentary Research 73 (2003), pp. 367-388.

Powell and Cooper, 2002 R. D. Powell and J. M. Cooper, A glacial sequence stratigraphic model for temperate, glaciated continental shelves. In J. A. Dowdeswell and C. O' Cofaigh, Editors, Glacierinfluenced Sedimentation on High-latitude Continental Margins, Geological Society of London Special Publication 203 (2002), pp. 215-244.

Powell et al., $2000>$ R. D. Powell, L. A. Krissek, and J. J. M. Van der Meer, Preliminary depositional environmental analysis of CRP2/2A, Victoria Land Basin, Antarctica: palaeoglaciological and palaeoclimatic inferences, Terra Antartica 7 (2000), pp. 313-322.

Prather et al., 1998 B. E. Prather, J. R. Booth, G. S. Steffens, and P. A. Craig, Classification, lithologic calibration, and stratigraphic succession of seismic facies of intraslope basins, deep-water Gulf of Mexico, American Association of Petroleum Geologists Bulletin 82 (1998), pp. 701-728.

Ravnås and Steel, $1998 \rightarrow$ R. Ravnås and R. J. Steel, Architecture of marine rift-basin successions, American Association of Petroleum Geologists Bulletin 82 (1998), pp. 110-146.

Rebesco et al., 2006 M. Rebesco, A. Camerlenghi, R. Geletti, and M. Canals, Margin architecture reveals the transition to the modern Antarctic ice sheet ca. 3 Ma, Geology 34 (2006), pp. 301-304.

Salvini et al., 1997 F. Salvini, G. Brancolini, M. Busetti, F. Storti, F. Mazzarini, and F. Coren, Cenozoic dynamics of the Ross Sea region, Antarctica: Crustal extension, intraplate strike-slip faulting and tectonic inheritance, Journal of Geophysical Research 102 (1997), pp. 24669-24696.

Saul et al., 1999 G. Saul, T. R. Naish, S. T. Abbott, and R. M. Carter, Sedimentary cyclicity in the marine Pliocene-Pleistocene of the Wanganui basin (New Zealand): Sequence stratigraphic motifs characteristic of the past 2.5 m.y., Geological Society of America Bulletin 111 (1999), pp. 524-537.

Stagpoole, 2004 V. Stagpoole, Bathymetry of the Ross Dependency and adjacent Southern Ocean. Institute of Geological and Nuclear Sciences Geophysical Map 17, 1:5,000,000 (2004).

Whittaker, 2005 J. Whittaker, Cenozoic structural and stratigraphic history of McMurdo Sound, Antarctica. MSc thesis, Victoria University of Wellington, New Zealand, 71 pp., 2005.

Wilson, 1995 T. J. Wilson, Cenozoic transtension along the Transantarctic Mountains - West Antarctic Rift boundary, southern Victoria Land, Antarctica, Tectonics 14 (1995), pp. 531-545.

Wilson et al., 1998 G. S. Wilson, A. P. Roberts, K. L. Verosub, F. Florindo, and L. Sagnotti, Magnetobiostratigraphic chronology of the Eocene-Oligocene transition in the CIROS-1 core, Victoria Land margin, Antarctica: Implications for Antarctic glacial history, Geological Society of America Bulletin 110 (1998), pp. 35-47.

Wilson et al., 2004 T. J. Wilson, L. A. Lawver, S. A. Henrys, S. Mukasa, H. Horgan, M. Weiderspahn, M. Davis, J. Whittaker, A. Lowe, and M. Watson, Cruise Report NBP0401 19 January to 18 February 2004 - McMurdo Station to McMurdo Station, Ross Sea, Antarctica, New Zealand Institute of Geological and Nuclear Sciences Science Report 2004/03 (2004) 85 pp. .

Wilson et al., submitted for publication $-\mathrm{T}$. J. Wilson, S. A. Henrys, M. J. Hannah, R. Jarrard, C. R. Fielding, P. J. Barrett, and T. Paulsen, New rift history for West Antarctica. Submitted for publication in Geology.

Zachos et al., 2001 J. Zachos, M. Pagani, L. Sloan, E. Thomas, and K. Billups, Trends, rhythms and aberrations in global climate $65 \mathrm{Ma}$ to present, Science 292 (2001), pp. 686-693. 